\title{
Flint manufacturing of the Globular Amphorae culture at the site Wilczyce 10 (Lesser Poland) in the context of inventories from the neighbouring areas
}

\author{
Výroba štípané industrie v kultuře kulovitých amfor na stanici \\ Wilczyce 10 (Malopolsko) v kontextu litických inventářů \\ ze sousedních oblastí
}

Tomasz Boroń - Małgorzata Winiarska-Kabacińska

\begin{abstract}
The paper discusses three flint inventories of the Globular Amphorae culture from the site in Wilczyce located on the Sandomierz Upland (Świętokrzyskie Voivodeship, Lesser Poland). The said inventories were collected during the exploration of settlement-type pits. The paper also includes a functional analysis of all tools and blades and the collection of selected flakes. The raw material structure of the discussed inventories shows that the Late Neolithic communities from Wilczyce primarily used Świeciechów flint, while based on the analyses of microdamage it was established that the dominating activity was treating and processing plants, whereas other organic materials such as hides, wood, and bone and antler were less often treated at that site. According to ${ }^{14} \mathrm{C}$ dates, communities of the Globular Amphorae culture settled in the Wilczyce microregion in the earliest phase of that culture's expansion on the Sandomierz Upland area.

Late Neolithic - Globular Amphorae culture - flint manufacturing - analyses of microdamage - Poland

Př́spěvek pojednává o třech inventárích štípané industrie ze stanice Wilczyce na Sandoměřské pahorkatině (Svatokř́žšé vojvodství). Soubory pocházeji ze sídlištních jam z doby kultury kulovitých amfor. Připojena je funkční analýza všech nástrojü, čepelí a vybraných úštěpů. Surovinové spektrum ukazuje, že pozdně neolitické komunity ve Wilczycích používaly hlavně świeciechovský silicit. Dle rozboru mikrostop poškození byla hlavní činností práce s rostlinami, zatímco jiné organické materiály, jako kůže, dřevo, kosti a parohy, byly zpracovávány méně. Dle ${ }^{14} \mathrm{C}$ dat obývala populace kultury kulovitých amfor dotyčný region již v nejstarši fázi expanze této kultury do Sandoměřské pahorkatiny.
\end{abstract}

pozdní neolit - kultura kulovitých amfor - výroba štípané industrie - analýza mikrostop - Polsko

\section{Introduction}

The site in Wilczyce, located on the Sandomierz Upland (Świętokrzyskie Voivodeship, Lesser Poland; fig. 1a) was discovered in 1994 during a systematic field survey carried out as a part of the Polish Archaeological Record project (Kowalewska-Marszatek - Wtodarczak 2002, 21). Archaeological excavations commenced in 1998. ${ }^{1}$ Until 2010, the main objective of these investigations was to determine the extent of the Magdalenian culture's settlement and their results were published in a form of a book edited by Romuald Schild

\footnotetext{
1 The research was financed by the Voivodeship Heritage Protection Office (Wojewódzki Urzqd Ochrony Zabytków) in Kielce, the Institute of Archaeology and Ethnology of the Polish Academy of Sciences in Warsaw and Karpacka Spółka Gazownictwa sp. z o. o. - Sandomierz Division.
} 


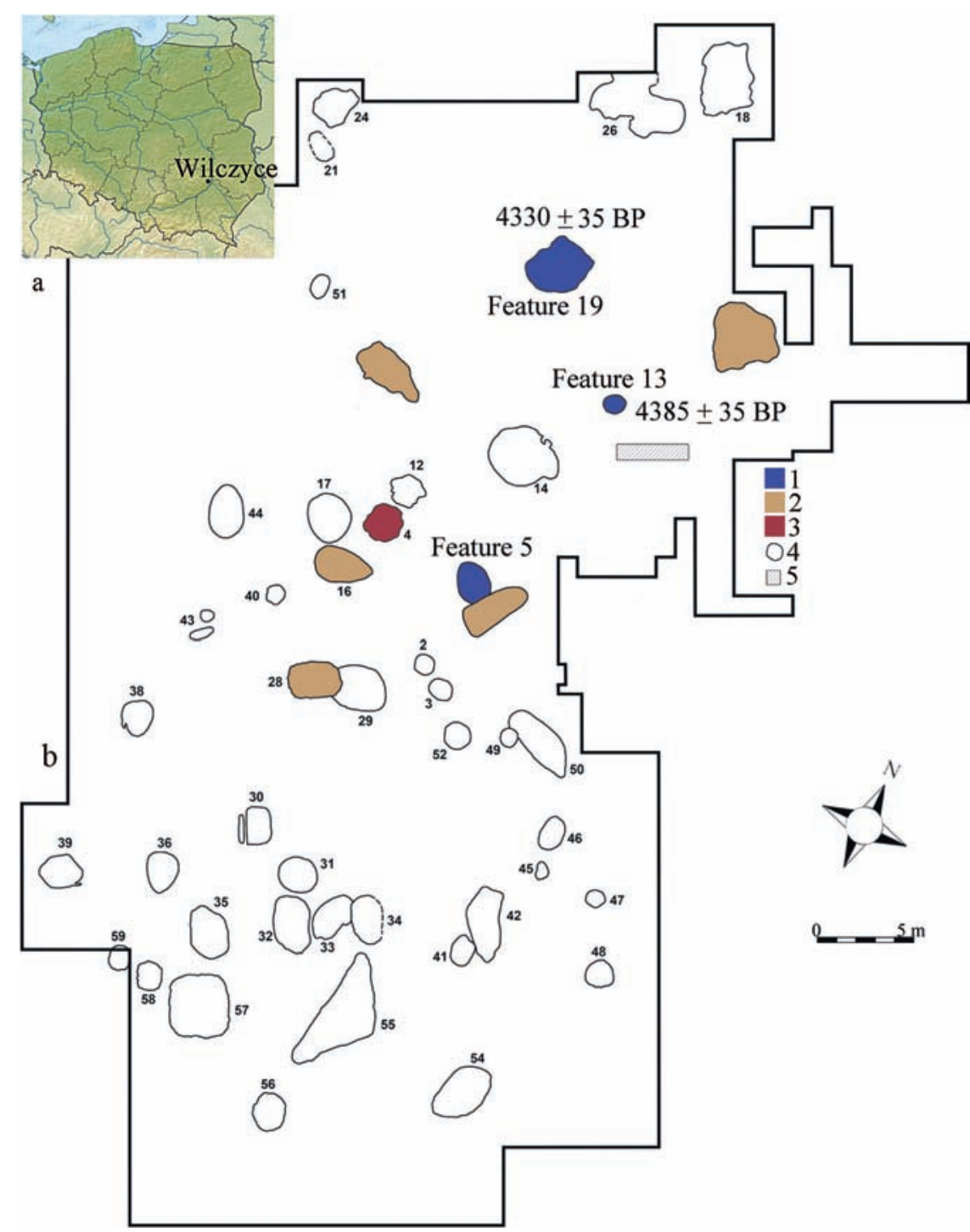

Fig. 1. $a$ - location of the Wilczyce site, b-site plan. 1 - features of the Globular Amphorae culture; 2 - features of the Corded Ware culture; 3 - features from the Early Bronze Age; 4 - other Neolithic features; 5 - balk preserved in situ. Map of Poland downloaded from www.mapsland.com.

(2014). However, during the subsequent archaeological excavations, researchers discovered numerous features from the Neolithic period and the Bronze Age, some associated with the occupation of the site and economic activities and some of a funerary nature (fig. $1 \mathrm{~b}$; Boroń 2013, 131-135; 2017; Włodarczak et al. 2016). In total, so far around 20 ares have been excavated, with 75 recorded features.

Based on ${ }^{14} \mathrm{C}$ dates and the analysis of pottery material, it was possible to identify several phases of the prehistoric settlement associated with the Late Neolithic (Globular 

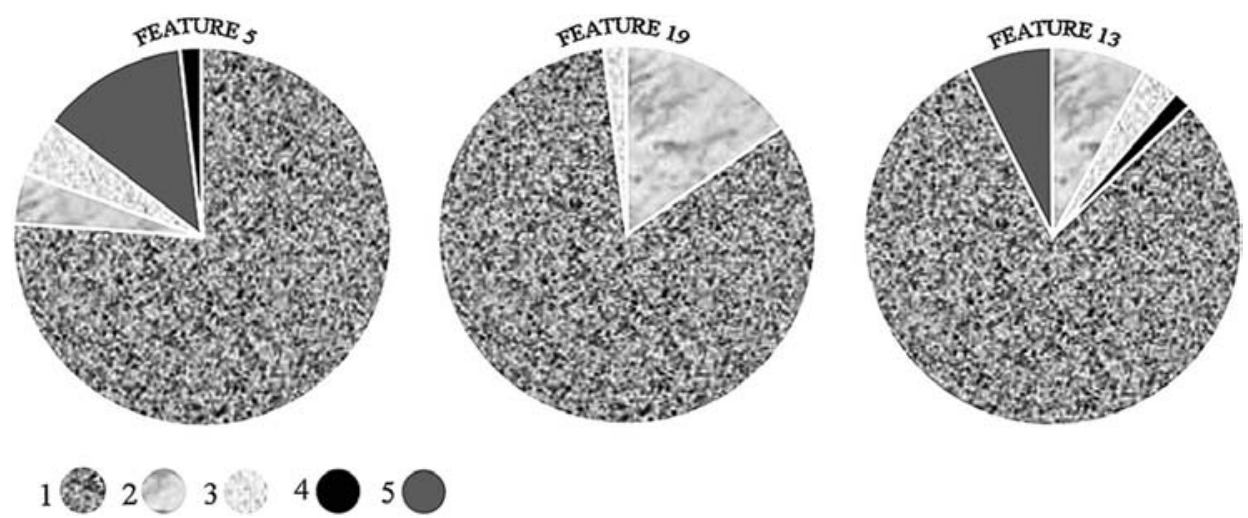

Fig. 2. Wilczyce, site 10. Raw material structure in individual features. 1 - Świeciechów flint; 2 - chocolate flint; 3 - banded flint; 4 - Cretaceous flint; 5 - unidentified material (figs. 2, 24, 25 by T. Boroń).

Amphorae culture, Corded Ware culture), and the Early and Middle Bronze Age (Mierzanowice culture, Trzciniec culture). The excavated features included settlement-type pits, production features (slag-pits, combustion features and probably pits for firing pottery), functional (hearths), and burial pits. The latter contained human and animal burials. Features associated with the settlement were characterised by rich assemblages of archaeological sources, their variety, and good state of preservation.

Material sources, in particular pottery associated with the occupation of the site by the Globular Amphorae culture, was retrieved from a relatively large number of features (around 30). However, there were concerns (in many instances justified) that it was a byproduct of the later settlement at the site, i.e., an interference in chronologically younger features. To minimise - or even eliminate - the potential discrepancies in the dating of the features, archaeologists analysed in detail all obtained archaeological sources. From the group of numerous features, researchers selected three in the case of which they were certain that they represented the settlement cycle of the Globular Amphorae culture. The key criterion was the presence of pottery vessels and their vertical scattering in fills of the features. In the three selected pits, such finds were deposited both at the bottom and in the ceiling of each feature. Aspects of flint manufacturing were discussed on the basis of assemblages retrieved from features number 5, 13, and 19. In addition to the flint material, a detailed analysis of other archaeological finds, including stone artefacts, covered only feature 13. The stone finds recorded in that feature were three pads/slabs, one tool for grinding/polishing, and one polishing stone/whetstone. ${ }^{2}$

According to the cartographic records documenting the density of the Globular Amphorae culture settlement on the Sandomierz Upland, the number of sites discovered in that region during the field survey is rather high (Kowalewska-Marszałek 2019, 121). However, regular archaeological excavations are carried out only on just a few of these sites.

\footnotetext{
2 Katarzyna Kerneder-Gubała: „Materiały kamienne z ob. 13 na stanowisku Wilczyce 10”. Manuscript kept in the Archives of the Centre for Interdisciplinary Archaeological Research of the Institute of Archaeology and Ethnology, Polish Academy of Sciences in Warsaw.
} 


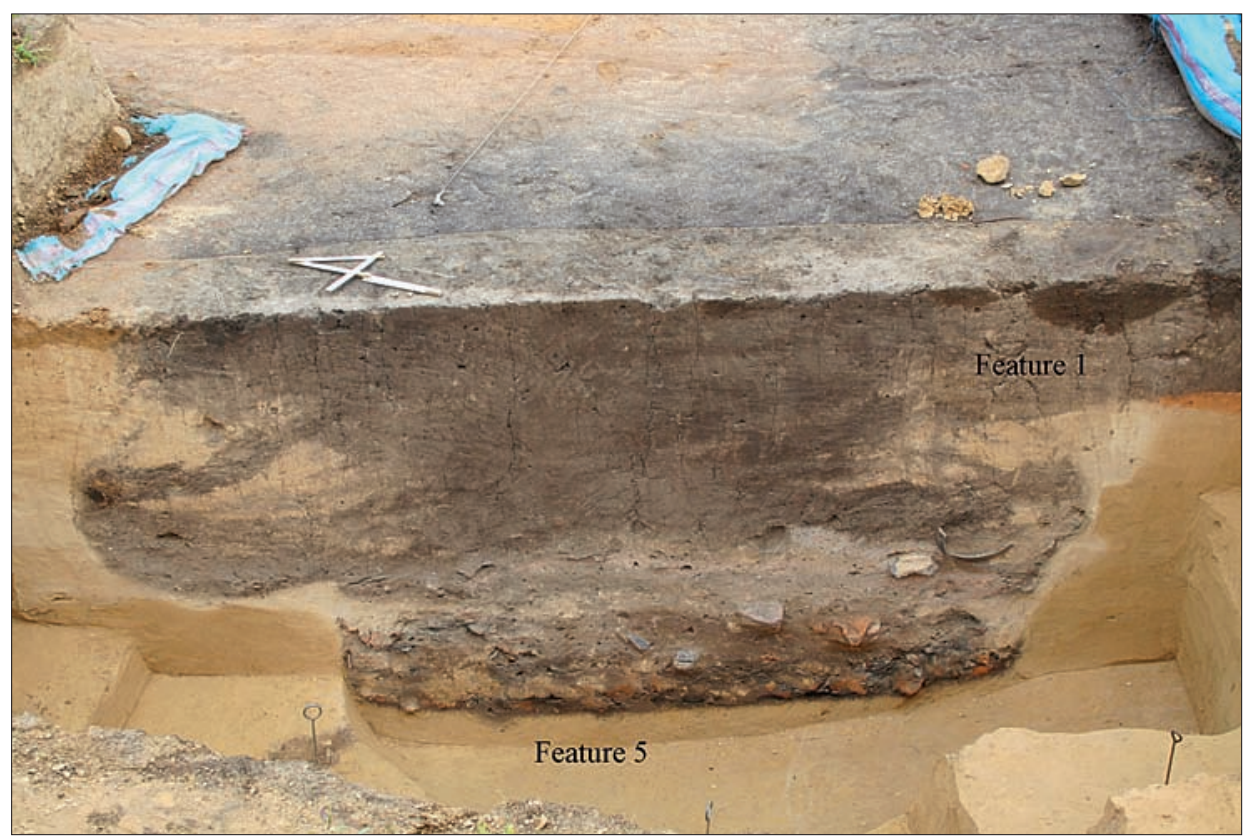

Fig. 3. Wilczyce, site 10. Profile of feature 5 (photo H. Królik).

\section{Materials and methods}

The flint material collected from the three selected features was characterised by the similar structure of the assemblages composed of flakes, sparse blades, and tools, although tool assemblages differed slightly in terms of the number of specimens and identified types of tools, which means that their spectrum is rather broad and diverse.

Definitely, the dominating raw material is Świeciechów flint, which seems to be justified considering the small distance between the site and deposits of that material (Balcer 1971; 1975; Libera-Zakościelna 2002). However, as evidenced by the studies on the use of the flint material on the Sandomierz Upland, the increase in the proportion of Świeciechów flint in the inventories from the Late Neolithic is a common tendency (KowalewskaMarszałek 2002).

Chocolate flint and banded flint were used much less often, whereas there were only a few artefacts made from Cretaceous flint (fig. 2).

Finds made from Świeciechów flint are characterised not only by the number of specimens but also their size. In the case of other materials, except for core specimens (axes, cores, splintered pieces), the length of artefacts does not exceed $2-3 \mathrm{~cm}$.

During the excavation of fills in features 5,13 , and 19, only the soil from feature 5 was partly floated - hence the significant difference in the number of chips and small flint waste from that feature and finds collected from the other two features.

Considering the homogeneity of archaeological sources, a group of flint finds was chosen from the three features, including a core, splintered pieces, all blade specimens, and selected flakes, which were then analysed to establish if those specimens had been used. 


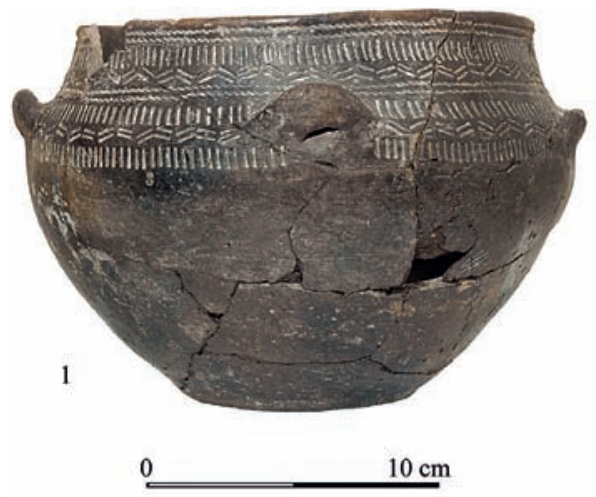

Fig. 4. Wilczyce, site 10, feature 5. Pottery vessels (photo M. Osiadacz).

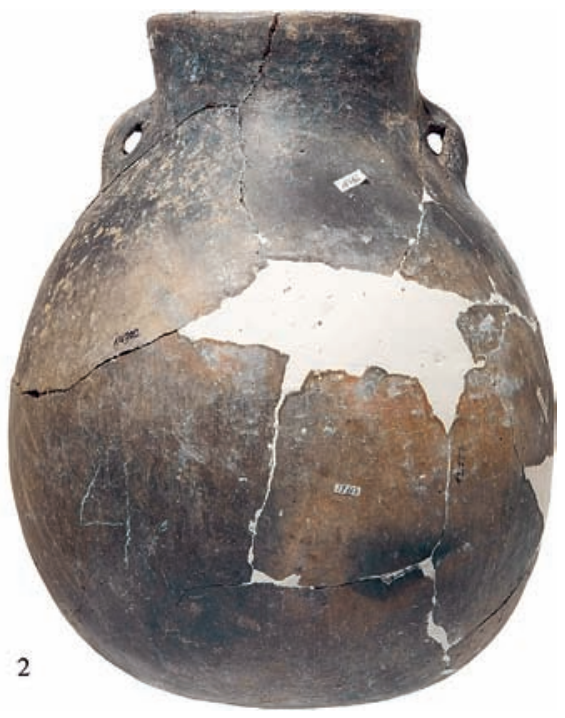

The study was conducted using the microwear analysis through the microscopic observation of the surfaces and edges of flint artefacts. The said analysis was conducted using Olympus SZX9 stereoscopic microscope and Olympus BX53M metallographic microscope, at a magnification of ten and several hundred times. Traces recorded under the microscope, resulting from the use of individual tools, took the form of rounded edges, abrasions, damage, and burnishing, and allowed us to determine the function of the selected artefacts. That method is based on the previously conducted experiments aimed at recreating the process of making specific tools and then using them to perform various actions associated with the functioning of prehistoric communities. Observations of these tools, recording all visible transformations and comparing them with traces detected on archaeological specimens enables researchers to formulate a hypothesis concerning how and for what purpose given artefacts were used. That method, proposed in the 1970s (among others, Keeley - Newcomer 1977; Semenov 1964), was further developed and improved in the next decades (inter alia Keeley 1980; Moss 1983; Plisson 1985; Van Gijn 1989), and subsequently enriched by the studies on the surviving remains (e.g., Haslam 2006; Langejans 2010), and became a key element in the interpretation of artefacts aimed at understanding their function - both in relation to individual tools and the entire assemblage of the analysed artefacts - but also the function of the site itself.

Feature 5 is a pit with a diameter of around $2 \mathrm{~m}$ and a depth of $1.8 \mathrm{~m}$. It has a stepped profile and a two-part fill. The upper part of the pit constitutes dark grey soil, whereas the bottom part is filled with several strata of yellow loess, dark soil, and thin layers of scattered daub (fig. 3). The feature contained very large quantities of archaeological material, in particular pottery - of which it was possible to piece together a dozen or so almost complete vessels (fig. 4). In addition to that category of finds, archaeologists retrieved also a relatively large number of animal bones and pieces of daub. The upper part of the feature was damaged by the later settlement activity of the Corded Ware culture community.

During the exploration, archaeologists collected in total 386 flint specimens, of which the majority constituted chips and flint waste. The inventory is composed of cores, flake, and blade semi-raw material, and 6 tools.

Cores. Two specimens were identified. These were flake cores with multiple flaking surfaces of a similar size. ${ }^{3}$ Chip scars are small and very clear (fig. 5: 1-2).

${ }^{3}$ Dimensions of all tools together with the indication of the raw material are listed in table 1 . 


\begin{tabular}{|c|c|c|c|c|c|}
\hline $\begin{array}{l}\text { Inventory } \\
\text { category }\end{array}$ & $\begin{array}{l}\text { Length } \\
\text { in } \mathrm{mm}\end{array}$ & $\begin{array}{l}\text { Width } \\
\text { in } \mathrm{mm}\end{array}$ & $\begin{array}{l}\text { Thickness } \\
\text { in } \mathrm{mm}\end{array}$ & Raw material & Fig. \\
\hline \multicolumn{6}{|c|}{ Feature 5} \\
\hline core & 56 & 37 & 19.3 & banded flint & $5: 2$ \\
\hline core & 59 & 30.5 & 26 & banded flint & 5: 1 \\
\hline flakes & & & & $\begin{array}{c}\text { Świeciechów flint (39 pieces), } \\
\text { chocolate flint (3 pieces), } \\
\text { banded flint (7 pieces) }\end{array}$ & \\
\hline blades & & & & $\begin{array}{c}\text { Świeciechów flint (2 pieces), } \\
\text { chocolate flint (1 pieces), } \\
\text { Cretaceous flint (1 piece) }\end{array}$ & \\
\hline axe & 100 & $\begin{array}{l}\text { width of a blade } 38 \text {; } \\
\text { width of a head } 22.5\end{array}$ & 15 & banded flint & 6 \\
\hline truncated blade & 38.6 & 16 & 3 & Świeciechów flint & 7: 7 \\
\hline borer & 42.5 & 17.3 & 5.8 & Świeciechów flint & 7: 11 \\
\hline retouched blade & 61 & 24 & 6.5 & Świeciechów flint & $7: 8$ \\
\hline retouched blade & 53.5 & 27.5 & 3.5 & Świeciechów flint & $7: 9$ \\
\hline scraper & 36.7 & 26 & 11 & chocolate flint & 7: 10 \\
\hline \multicolumn{6}{|c|}{ Feature 13} \\
\hline core & 54 & 36 & 18 & chocolate flint & $12: 2$ \\
\hline splintered piece & 48 & 34 & 16 & chocolate flint & 12: 3 \\
\hline splintered piece & 43 & 31 & 8.5 & banded flint & 12: 4 \\
\hline splintered piece & 34.5 & 21.5 & 9 & Świeciechów flint & 12: 1 \\
\hline flakes & & & & $\begin{array}{c}\text { Świeciechów flint (42 pieces), } \\
\text { chocolate flint ( } 2 \text { pieces), } \\
\text { banded flint (2 pieces), } \\
\text { Cretaceous flint (1 piece) }\end{array}$ & \\
\hline blades & & & & Świeciechów flint & \\
\hline axe & 126 & $\begin{array}{l}\text { width of a blade } 60 \text {; } \\
\text { width of a head } 30\end{array}$ & 21 & chocolate flint & 14 \\
\hline retouched flake & 47 & 35 & 5.5 & Świeciechów flint & $15: 7$ \\
\hline retouched flake & 45.8 & 50 & 9.5 & Świeciechów flint & 13: 4 \\
\hline retouched flake & 43.2 & 55.6 & 13.8 & Świeciechów flint & 15: 1 \\
\hline retouched flake & 58.3 & 39 & 10 & Świeciechów flint & $15: 3$ \\
\hline retouched flake & 54.8 & 59 & 12 & Świeciechów flint & $15: 5$ \\
\hline retouched flake & 42.7 & 39.4 & 5.5 & Świeciechów flint & $15: 2$ \\
\hline retouched flake & 35 & 40 & 9.5 & Świeciechów flint & $15: 4$ \\
\hline retouched flake & 25.3 & 31.6 & 7 & Świeciechów flint & \\
\hline retouched flake & 27.6 & 70 & 6.6 & Świeciechów flint & \\
\hline retouched flake & 38.5 & 43 & 10.2 & Świeciechów flint & \\
\hline truncated blade & 27.6 & 13.2 & 4.5 & Świeciechów flint & 13: 6 \\
\hline truncated blade & 54.8 & 16.4 & 3.7 & chocolate flint & 13: 10 \\
\hline notched tool & 14 & 19.3 & 3.3 & chocolate flint & 13: 13 \\
\hline burin & 24 & 11.7 & 3 & chocolate flint & 13: 9 \\
\hline scraper & 20 & 36 & 6.8 & Świeciechów flint & 13: 7 \\
\hline retouched blade & 33.5 & 11.5 & 6.4 & banded flint & 13: 12 \\
\hline retouched blade & 30 & 18.5 & 4.8 & Świeciechów flint & 13: 11 \\
\hline retouched blade & 28.8 & 13.5 & 2 & Świeciechów flint & \\
\hline retouched blade & 28 & 20 & 3 & Świeciechów flint & 13: 8 \\
\hline retouched chunk & 32 & 23.5 & 8 & Świeciechów flint & \\
\hline retouched chunk & 31 & 59 & 10 & Świeciechów flint & $15: 8$ \\
\hline other & 33 & 33 & 16 & Świeciechów flint & $15: 6$ \\
\hline
\end{tabular}




\begin{tabular}{|c|c|c|c|c|c|}
\hline \multicolumn{6}{|c|}{ Feature 19} \\
\hline splintered piece & 29 & 11.6 & 9.5 & Świeciechów flint & $20: 3$ \\
\hline flakes & & & & $\begin{array}{l}\text { Świeciechów flint (17 pieces), } \\
\text { chocolate flint ( } 3 \text { pieces) }\end{array}$ & \\
\hline blades & & & & Świeciechów flint & \\
\hline end-scraper & 69 & 37.4 & 7.7 & Świeciechów flint & $20: 9$ \\
\hline scraper & 40 & 40 & 11 & chocolate flint & $21: 4$ \\
\hline burin & 55 & 18 & 11.8 & Świeciechów flint & 20: 7 \\
\hline truncated blade & 61 & 13 & 5.8 & Świeciechów flint & $20: 10$ \\
\hline denticulate tools & 56.7 & 30 & 10 & Świeciechów flint & $21: 2$ \\
\hline perforator & 27.3 & 20 & 4.4 & Świeciechów flint & 20: 6 \\
\hline retouched blade & 46.7 & 17.3 & 6.5 & Świeciechów flint & $21: 1$ \\
\hline $\begin{array}{l}\text { projectile points } \\
\text { (fragment) }\end{array}$ & & & & chocolate flint & $20: 8$ \\
\hline retouched flake & 25.7 & 18.6 & 2.9 & Świeciechów flint & $21: 3$ \\
\hline retouched flake & 33 & 22.3 & 4 & Świeciechów flint & \\
\hline retouched flake & 40 & 24.6 & 12.5 & Świeciechów flint & \\
\hline fragments of tool & & & & chocolate flint & \\
\hline
\end{tabular}

Tab. 1. Classification of flint artefacts.

Flakes. There were 49 specimens (figs. $5: 3 ; 7: 1-3$ ). Usually, these are one-directional negative flakes. Only five specimens were partly cortical. Butts are usually plain, less often dihedral, cortical, prepared, and linear.

Blades. Four specimens were recorded. These are scar specimens with plain and dihedral butts. Edges of the blades are parallel, with straight profiles (fig. 7: 4-6).

Axes. Only one specimen was identified. All surfaces are polished. The axe has a symmetrical outline and a slightly convex cutting edge. The longitudinal profile has a lenticular shape tapering towards the butt and the cutting edge (fig. 6 ).

Truncated blades. Only one specimen was identified - with an oblique truncation on the edge transverse to the artefact's axis (fig. 7: 7).

Borers. One specimen made from an oblong flake was recorded (fig. 7: 11).

Retouched blades. There were two specimens. The retouching is regular, placed on the edges and covering their large sections (fig. 7: 8-9).

Scrapers. Only one such artefact was recorded. Both lateral edges were finished with semi-abrupt retouching (fig. 7: 10).

Results of the microscopic analysis:

The subjects of the analyses were all tools and unworked blades and seven selected unworked flakes (tab. 1). Transformations recorded on edges and surfaces of ten specimens were the results of using the tools (fig. 8).

Microdamage observed on the protruding, slightly smoothed part of the borer (fig. 8: 1) was caused by boring/carving in an unspecified raw material.

Both lateral edges of the truncated blade (fig. 8: 2) bear intensive traces of cutting plants (fig. 9: 1a-b).

Both analysed retouched blades were used - one for cutting some sort of soft organic material (fig. 8: 3) and the second one (fig. 8: 4) for scraping and cutting plants/wood (fig. 9:2), while the traces indicate the presence of an additional abrasive factor.

In the group of unworked blades, three specimens (fig. 8: 5-7) had transformations indicating that they were used to perform various actions during the processing of plants (fig. 9: $3 a-b$ and 4 ), whereas in the case of unworked flakes only two specimens had use-wear transformations, and they were used for cutting an unspecified raw material (fig. 8: 8-9). 

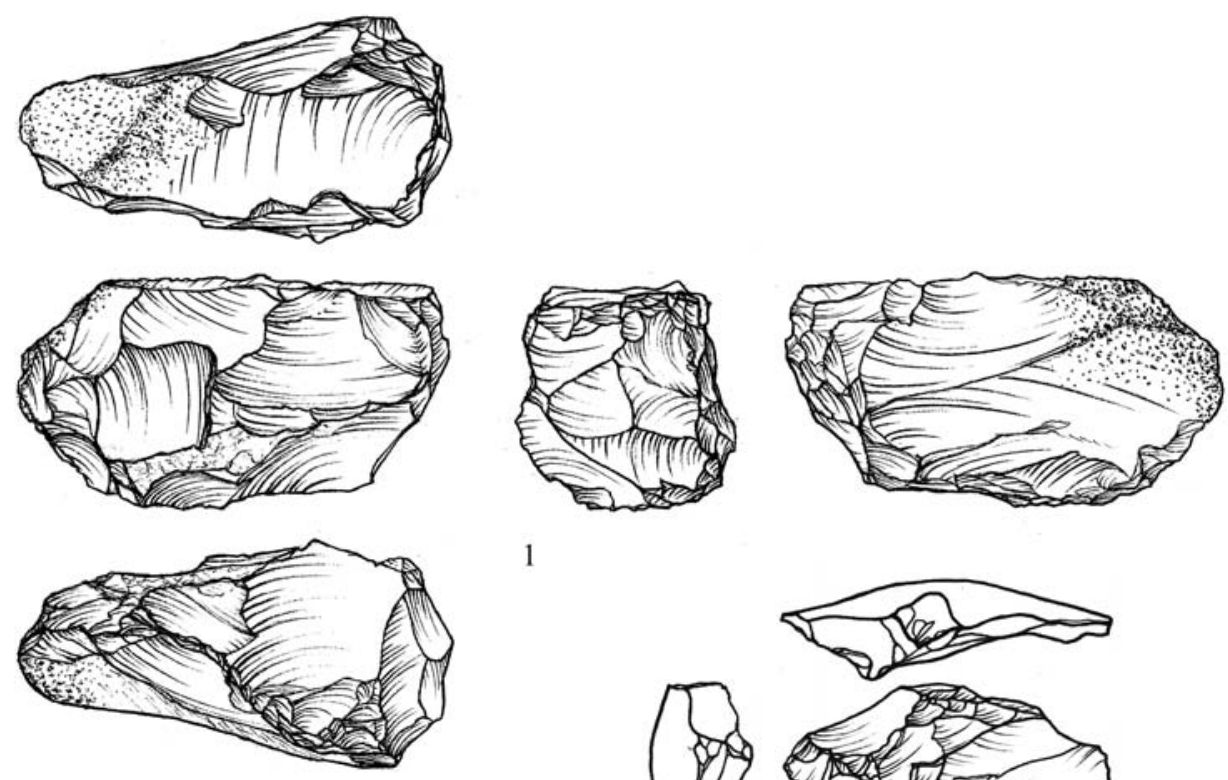

1
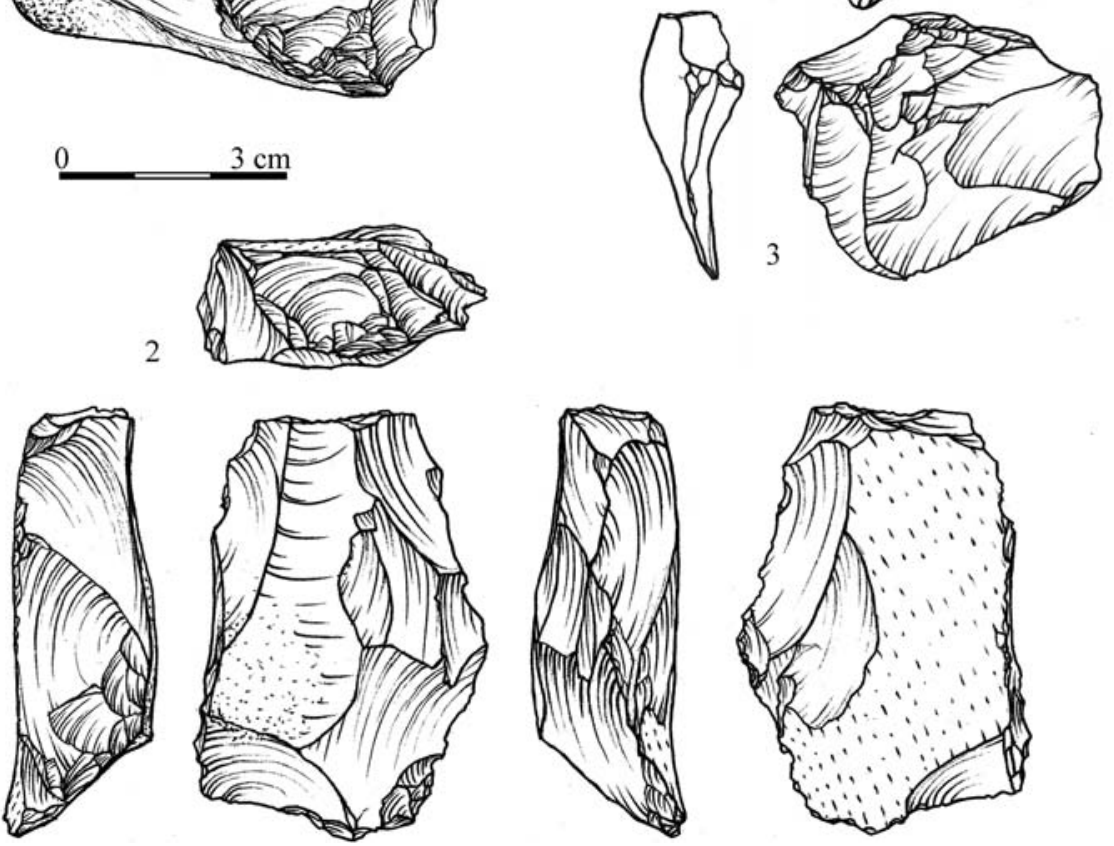

Fig. 5. Wilczyce, site 10, feature 5. Flint inventory. 1-2 - cores; 3 - flakes (drawings in figs. 5-7, 14, 15, 20 A. Pałasz).

Another subject of the studies was the flint axe used for woodworking, with clearly visible evidence of polishing and smoothing out surfaces, transformations associated with a haft and the blade with evidence of subsequent vertical polishing (fig. 10).

Feature 13 is a pit with a trapezoid cross-section (fig. 11), with a diameter of $80-90 \mathrm{~cm}$ at the top, $190 \mathrm{~cm}$ at the bottom, and $130 \mathrm{~cm}$ deep. The bottom of the feature constituted burnt natural orange loess. The upper part of the fill of the pit was light grey soil, below it - a layer of ash with a high content of charcoal. 
Fig. 6. Wilczyce, site 10, feature 5. Axe.
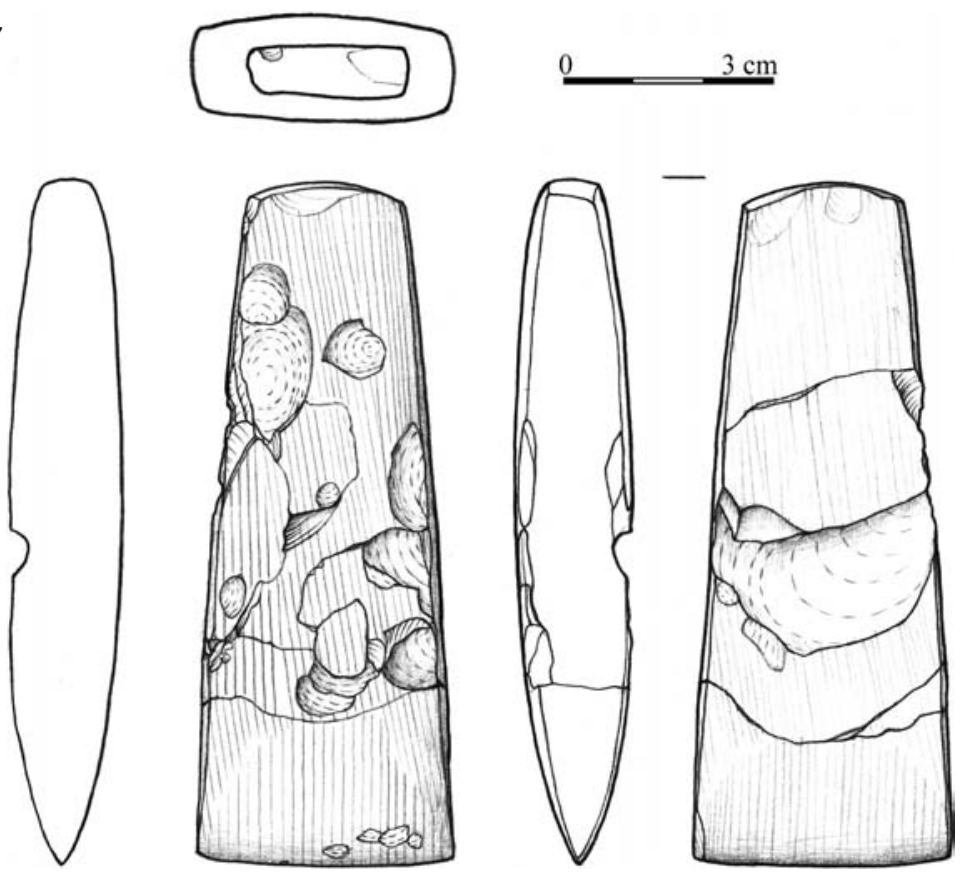

During the exploration of the feature, archaeologists collected several hundred pottery fragments. By piecing them together it was possible to reconstruct one complete vessel and several larger parts. Finds also included bone artefacts and animal bones, and shells.

The ${ }^{14} \mathrm{C}$ date obtained from the charcoal sample was $4385 \pm 35 \mathrm{BP}$ (Poz-96966). ${ }^{4}$

The flint assemblage discovered in the discussed feature was composed of cores, splintered pieces, flakes, a few blades, and tools, including a four-sided axe. ${ }^{5}$ In total, there were 122 specimens, including flint waste and chips.

Cores. One flake core with changed orientation was identified. The surviving four-sided shape suggests that it was a reused axe half-product (fig. 12: 2).

Splintered pieces. Three artefacts were identified - two with a sub-rectangular shape and one barrel-shaped (fig. 12:1 and 3). On the surface of one of the splintered pieces survived traces of polishing (fig. 12: 4).

Flakes. The assemblage contains 47 specimens (figs. 12: 5-9; 13: 1-3), including 43 non cortical specimens (the remaining ones have a cortical or natural surface). One and two-directional scars were recorded only in 10 cases. Flake butts are mainly smooth (30 specimens). The remaining flakes have dihedral, cortical, natural, linear, punctiform, and prepared butts. All other identified groups comprise several specimens.

Blades. Two artefacts were recorded. Dimensions of the first specimen were $50 \times 20 \times 7.3 \mathrm{~mm}$. On the narrower edge, there are visible two-dimensional scars (fig. 13: 5). The second blade is much shorter$22 \times 11.8 \times 3.5 \mathrm{~mm}$ respectively (fig. 13: 4).

\footnotetext{
${ }^{4}$ The funding for the dating of charcoal samples was provided by the Institute of Archaeology and Ethnology, Polish Academy of Sciences in Warsaw.

${ }^{5}$ Flints sometimes have surfaces damaged by calcium carbonate. This damage is marked on illustrations with a dashed line.
} 

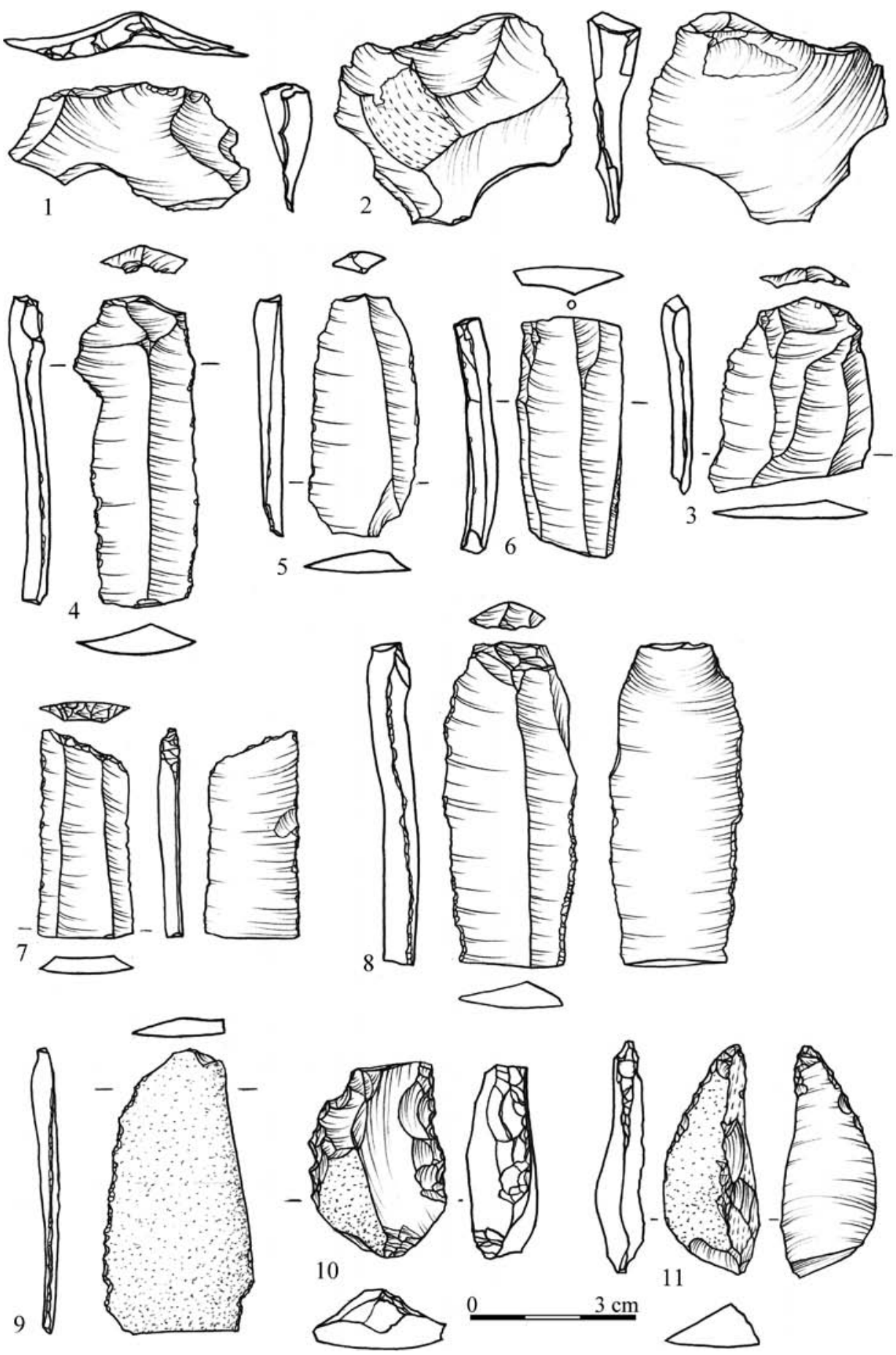

Fig. 7. Wilczyce, site 10, feature 5. Flint inventory. 1-3 - flakes; 4-6-blades; 7-11 - tools. 

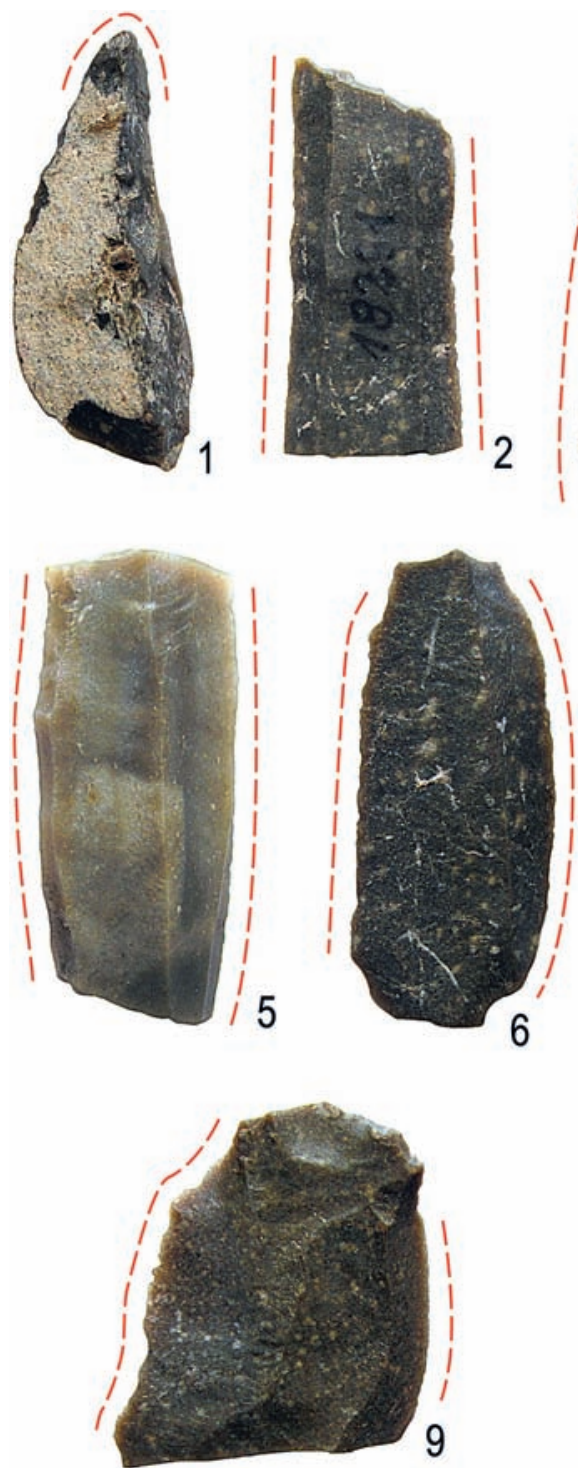
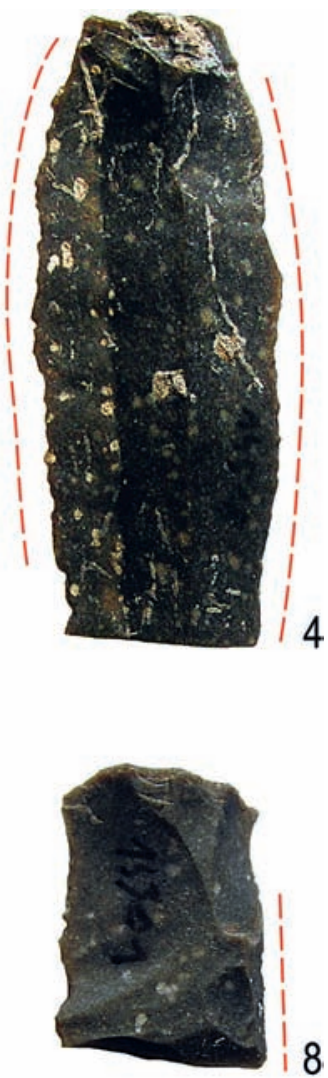

Fig. 8. Wilczyce, site 10, feature 5. Flint artefacts with evidence of use-wear. --- presence of use-wear traces; 1 - perforator; 2 - truncated blade; 3-4 - retouched blades; 5-7 - unworked blades; 8-9 - unworked flakes (figs. 8-9, 16-17, 22-23: photo M. Winiarska-Kabacińska, processing J. Kędelska)

Axes. Only one specimen was discovered. It is a form in the last stage of manufacturing, just before polishing (fig. 14).

Burins. There was only one truncation specimen, made from a regular flake (fig. 13: 9).

Scrapers. Only one specimen was identified. The retouching is obverse and semi-abrupt, located on the transverse edge (fig. 13: 7).

Truncated blades. Two artefacts were identified. Truncations are made transversely to the axis of the blade (fig. 13: 6 and 10). 

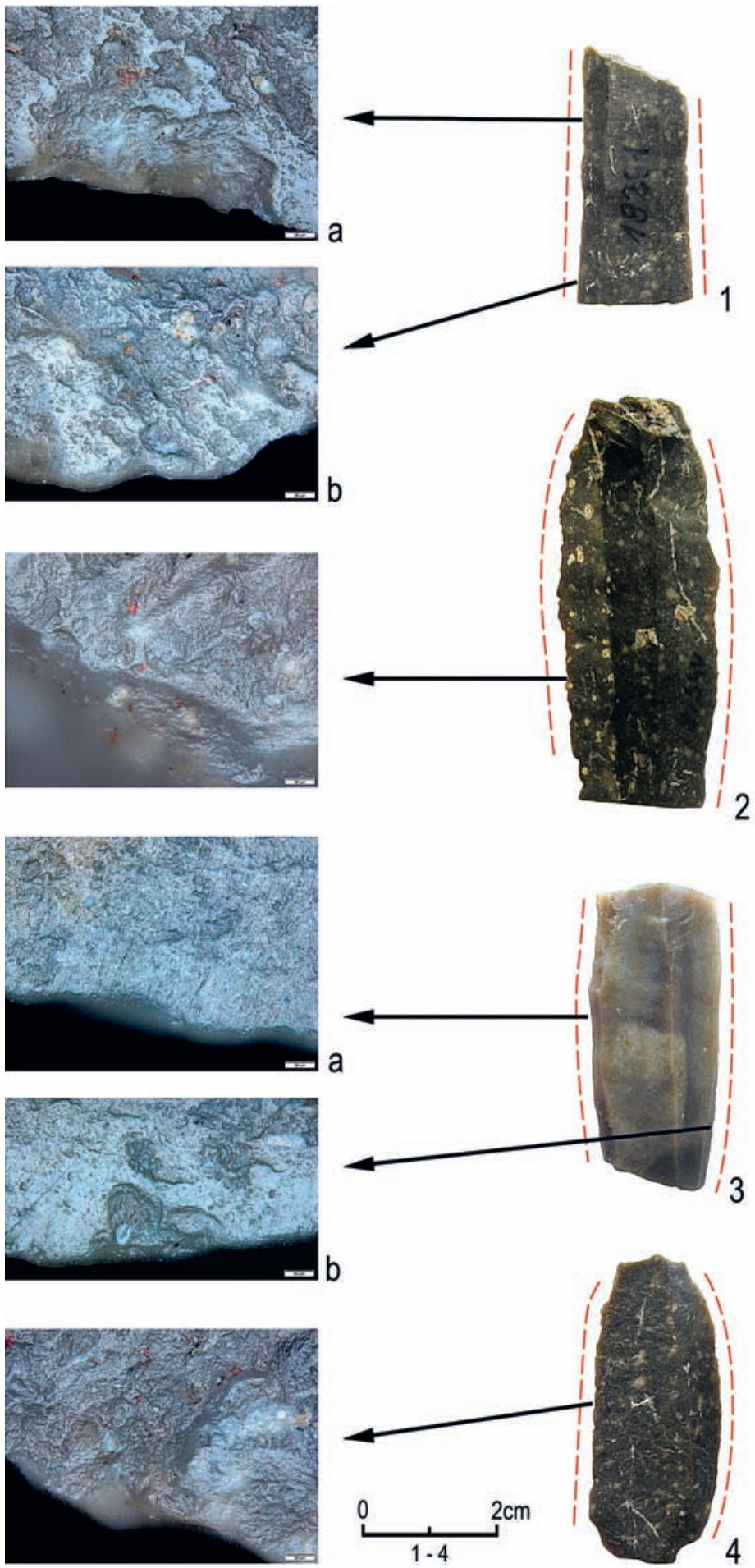

Fig. 9. Wilczyce, site 10, feature 5. Microscopic photographs: 1 - truncated blade, a, b: cutting crops; 2 - retouched blade: cutting plants/wood; 3 - blade, a, b: processing plants; 4 - blade: processing plants. 

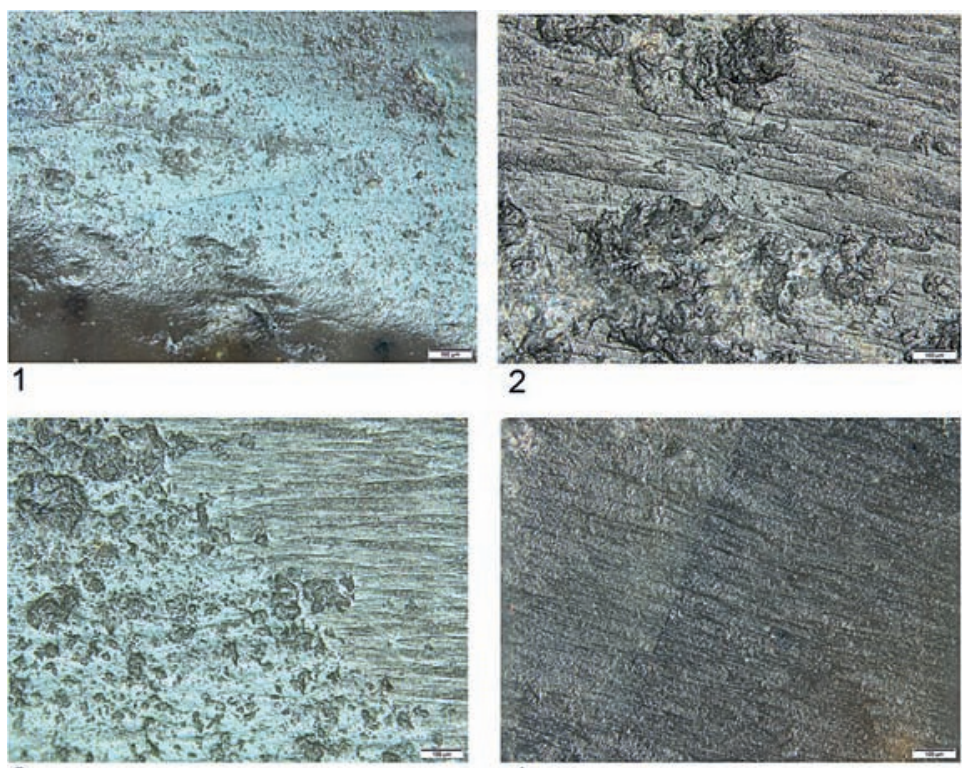

3
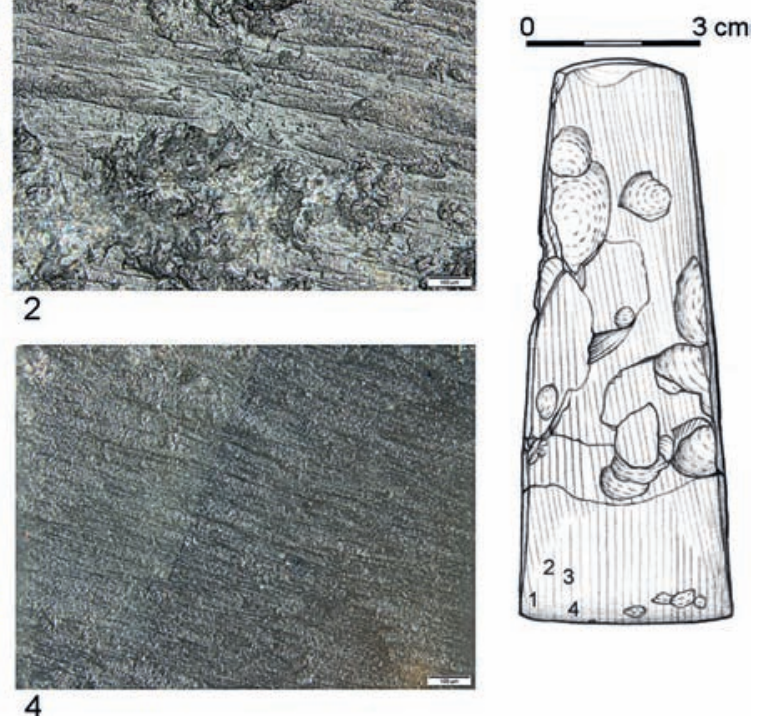

Fig. 10. Wilczyce, site 10, feature 5. Microscopic photographs: 1 - traces of woodworking; 2 - traces of polishing; 3 -traces of polishing and use; 4 - traces of polishing at the point (photo M. Winiarska-Kabacińska, drawing A. Pałasz).

Notched tools. One artefact made from a small flake was identified. The notch is retouched on the bulbar edge (fig. 13: 13).

Retouched blades. Four tools were recorded - one complete and two fragments (one with the apex and two from the middle part of a blade; fig. 13: 8 and 11-12). The retouching is delicate, regular, and discontinuous.

Retouched flakes. Ten specimens were identified. The retouch is usually delicate, regular, and covering small sections of the edge. The size of the flakes differs, with the length between 25 and $58 \mathrm{~mm}$ and width between 33 and $70 \mathrm{~mm}$ (figs. 13: 14; 15: 1-5 and 7).

Retouched chunks. Two specimens were identified. The first one is a flat waste with an inverse retouch (fig. 15: 8). The second specimen is also a flat chunk, thermally cracked and with an edge retouch.

Miscellaneous. Only one specimen was allocated to that category. It bears evidence of bifacial treatment (fig. 15: 6).

Results of the microscopic analysis:

The functional analysis covered the core, splintered pieces, all tools, two unworked blades, and eight selected unworked flakes. Both the core and splintered pieces had characteristic traces associated with their preparation and exploitation. On the surface of one of the splintered pieces there was visible evidence of polishing, which indicates that that specimen was made from a piece of a flint removed from a polished axe.

In the case of the remaining artefacts subjected to traseological observations, 14 specimens had usewear transformations (fig. 16).

Transformations visible on one of the transverse edges of the scraper (fig. 16: 1), in the form of crushing and associated brown-orange spots may indicate that the said piece was occasionally used as strike-a-light tool(?).

In the case of the two analysed truncated blades, only one specimen (fig. 16: 2) had use-wear traces on both lateral edges, which were caused by using the tool to work in bone or antler (fig. 17: 1). 


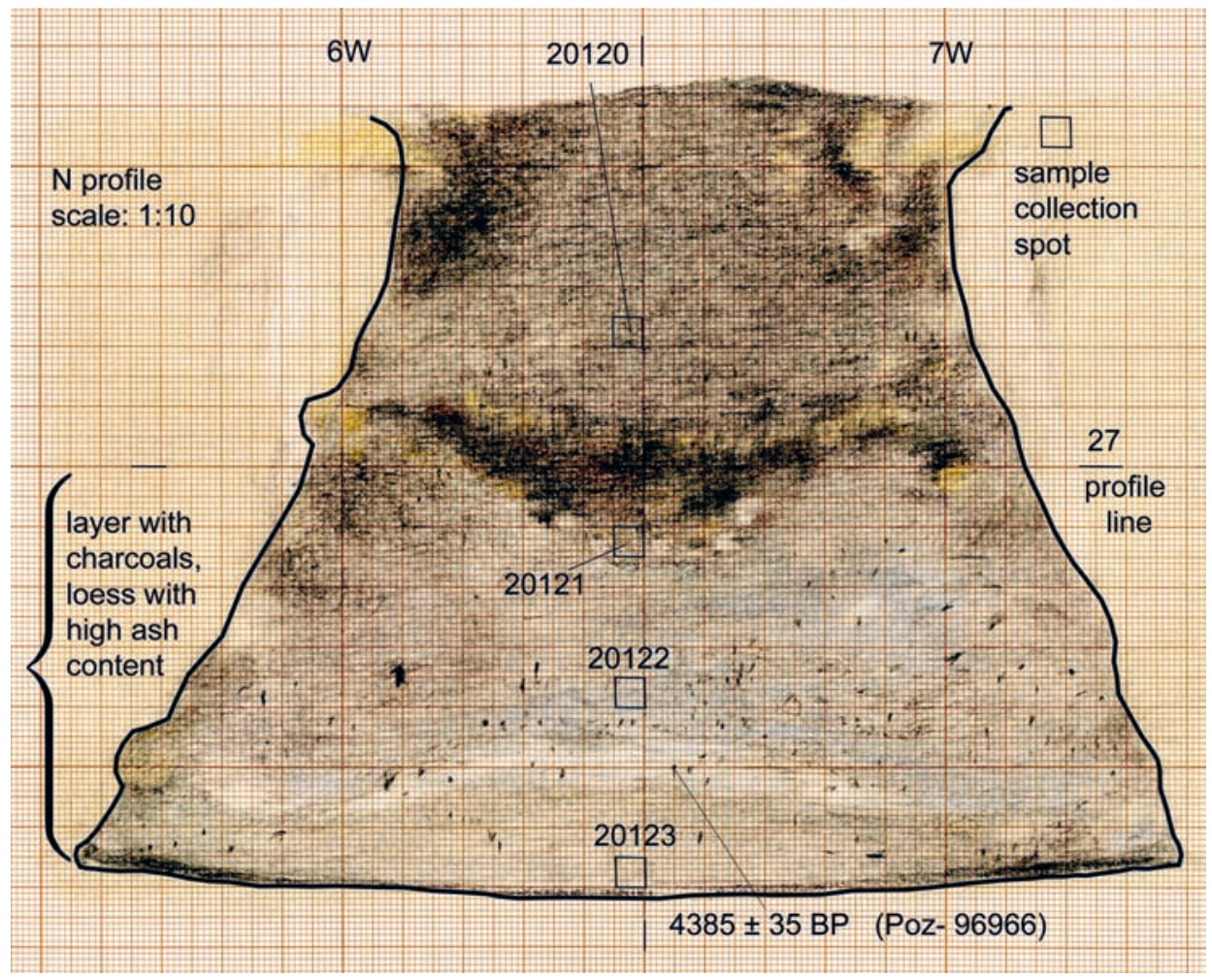

Fig. 11. Wilczyce, site 10, profile of feature 13 (drawing E. Gumińska).

Use-wear traces were also identified on two retouched blades, of which one was used to scrape bone (figs. 16: 3; 17:2), and the second one to treat bone/antler (figs. 16: 4; 17:3).

Five out of the nine analysed retouched flakes had use-wear transformations. One was used for cutting some sort of a soft organic material (fig. 16: 5) and the remaining specimens - for scraping and cutting wood and plants/wood (fig. 16: 6-8).

Use-wear traces were also present on the transverse and longitudinal edges of the retouched chunk and were created by scraping a non-organic material.

One of the two analysed unworked blades (fig. 16:9) was used to treat plants (fig. 17:4), as were the three of the unworked flakes (fig. 16: 10). On the surface of one of the flakes, there were visible traces of polishing indicating that it was removed from an axe.

Feature 19 is a relatively large pit with a diameter of over $3 \mathrm{~m}, 1.3 \mathrm{~m}$ deep and with a pear-shaped profile. The fill is rather uniform - dark grey, divided by a lighter layer of soil with inclusions of yellow loess (fig. 18). At the bottom, archaeologists discovered a concentration of pottery fragments that constituted parts of an almost complete vessel (fig. 19). In addition to the pottery, there were animal bones and several dozen flint specimens. The result of the laboratory analysis of a charcoal sample was $4330 \pm 35 \mathrm{BP}$ (Poz-112305).

In total, 62 specimens (including chips and flint waste) were collected from the fill. The discussed assemblage contained splintered pieces, flakes, blades, and 12 tools.

Splintered pieces. There was one bipolar specimen with a sub-rectangular shape (fig. 20:3).

Flakes. The assemblage of flakes comprised 20 specimens. Except for one partly cortical specimen, the remaining flakes belong to the scar category (fig. 20: 1-2). 

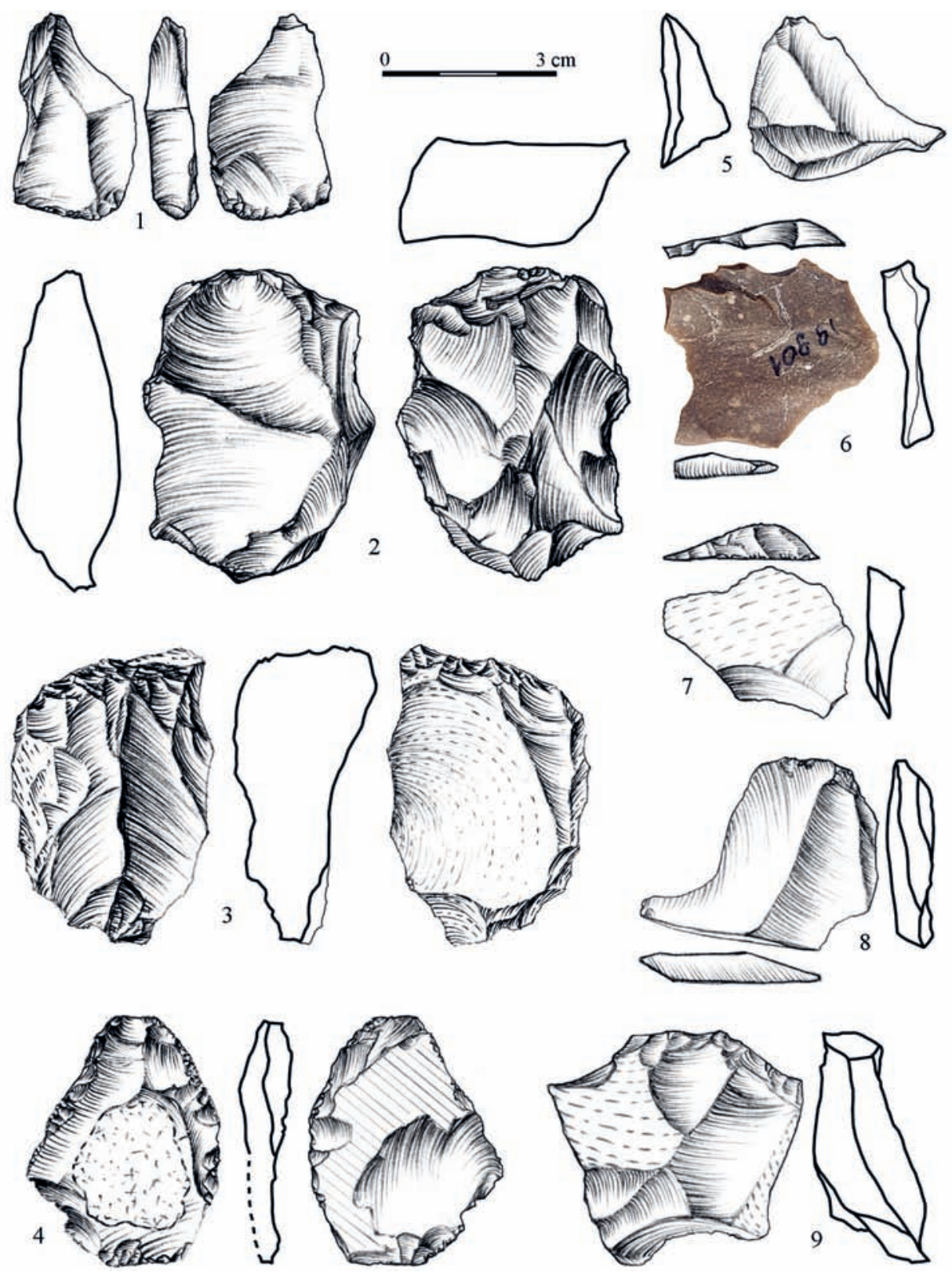

Fig. 12. Wilczyce, site 10, feature 13. Flint inventory. 1, 3, 4 - splintered pieces; 2 - core; 5-9-flakes (drawings E. Gumińska, A. Pałasz).

In terms of their size, they can be classified as small specimens, with the length not exceeding $33 \mathrm{~mm}$ at the width of $35 \mathrm{~mm}$. They usually have one-directional scars - only three specimens are characterised by two-dimensional scars. According to the identified types of butts, 14 flakes had smooth butts, 3 prepared butts, 1 natural, and 2 linear. 


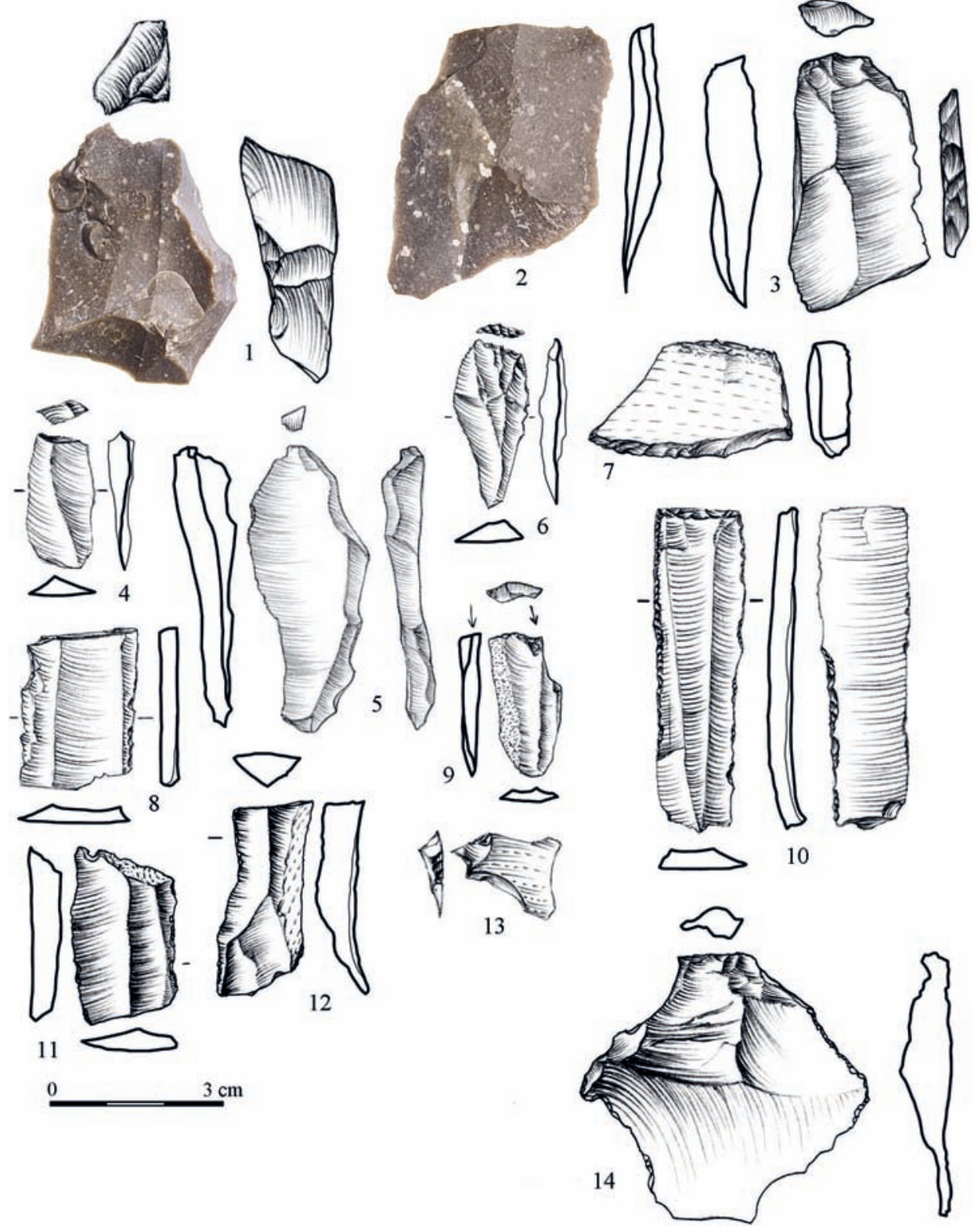

Fig. 13. Wilczyce, site 10, feature 13. Flint inventory. 1-3-flakes; $4-5$ - blades; 6-14-tools (drawings E. Gumińska, A. Pałasz; photo M. Osiadacz).

Blades. There were three artefacts - one complete specimen and two bulbar fragments (fig. 20: 4-5). The first one is $45 \mathrm{~mm}$ long, $16.5 \mathrm{~cm}$ wide, and $2.8 \mathrm{~mm}$ thick. In two cases butts are prepared and the third specimen has a natural butt.

Endscrapers. There was one artefact made from a large and wide blade. The butt is small and prepared and the bulb large and extensive (fig. 20: 9). 

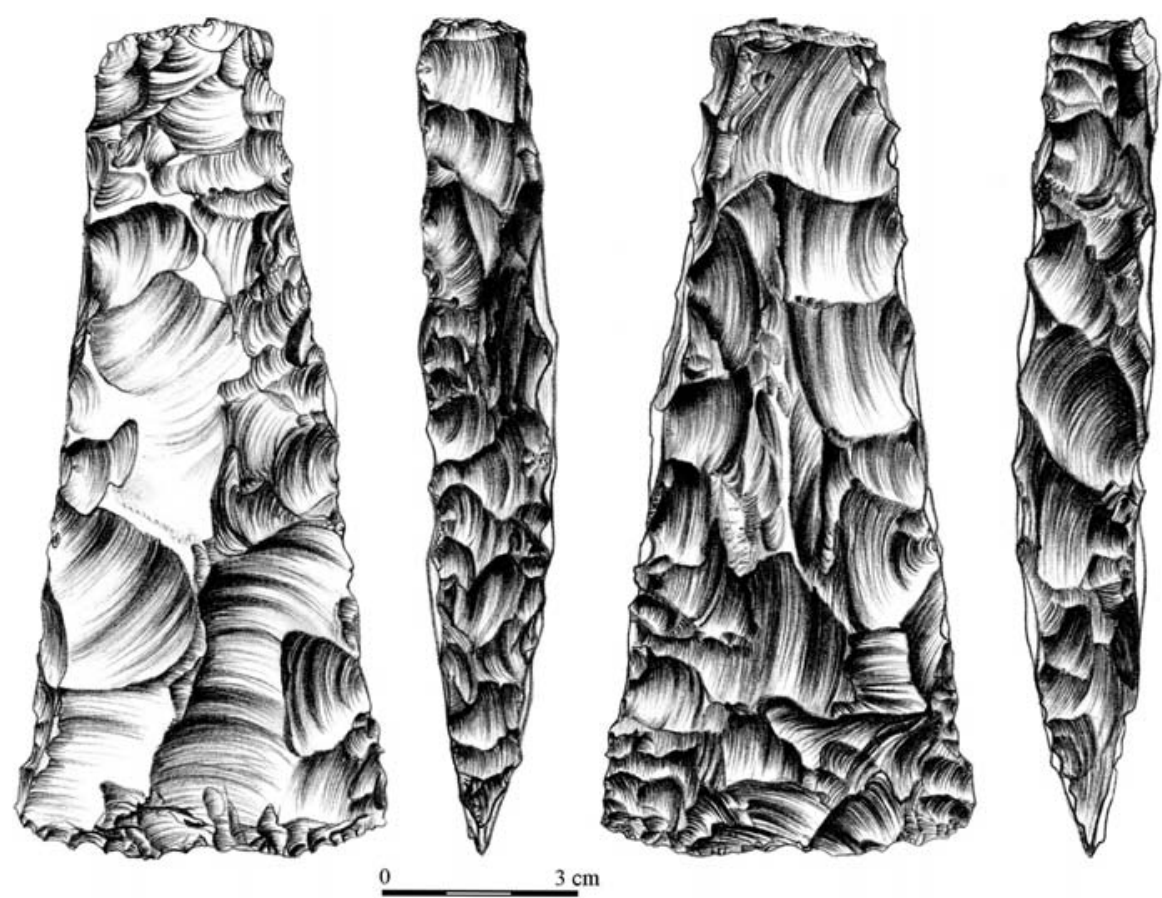

Fig. 14. Wilczyce, site 10, feature 13. Axe.

Burins. There was one specimen, allocated to the group of dihedral burins. It was made from a blade with the point formed in the bulbar part (fig. 20: 7).

Truncated blades. Only one blade specimen was allocated to that category. The semi-raw material used for its production has regular and straight edges. The truncation was formed perpendicularly to the axis of the discussed specimen (fig. 20:10).

Scrapers. Only one such artefact was recorded. The retouch is regular and abrupt, covering the ventral surface (fig. 21: 4). In addition, the discussed specimen has a retouched notch.

Perforators. Only one such find was identified. The grover sting was formed with an abrupt retouching in the apex part of the flake (fig. 20: 6).

Denticulate tools. There was only one specimen. The edge was formed with clear and deep blows (fig. 21:2).

Retouched blades. One such tool was identified. The retouch is delicate and regular, covering a small section of the edge (fig. 21: 1).

Retouched flakes. Three specimens were identified. They have similar size and retouch, i.e., delicate edge retouching (fig. 21:3).

Projectile points. One incomplete specimen was recorded, with a notch made with a bifacial retouch and one worked edge (fig. 20: 8).

Fragments of tools. Only one fragment was recorded.

Results of the microscopic analysis:

The analysis covered the splintered piece, all tools, three blades, and six unworked flakes. On the edges of the splintered piece there were visible marks associated with its manufacturing and exploitation. Both the blades and selected unworked flakes had no use-wear traces.

The burin from the discussed assemblage was covered with a thick layer of calcium carbonate, which made further observations impossible. 

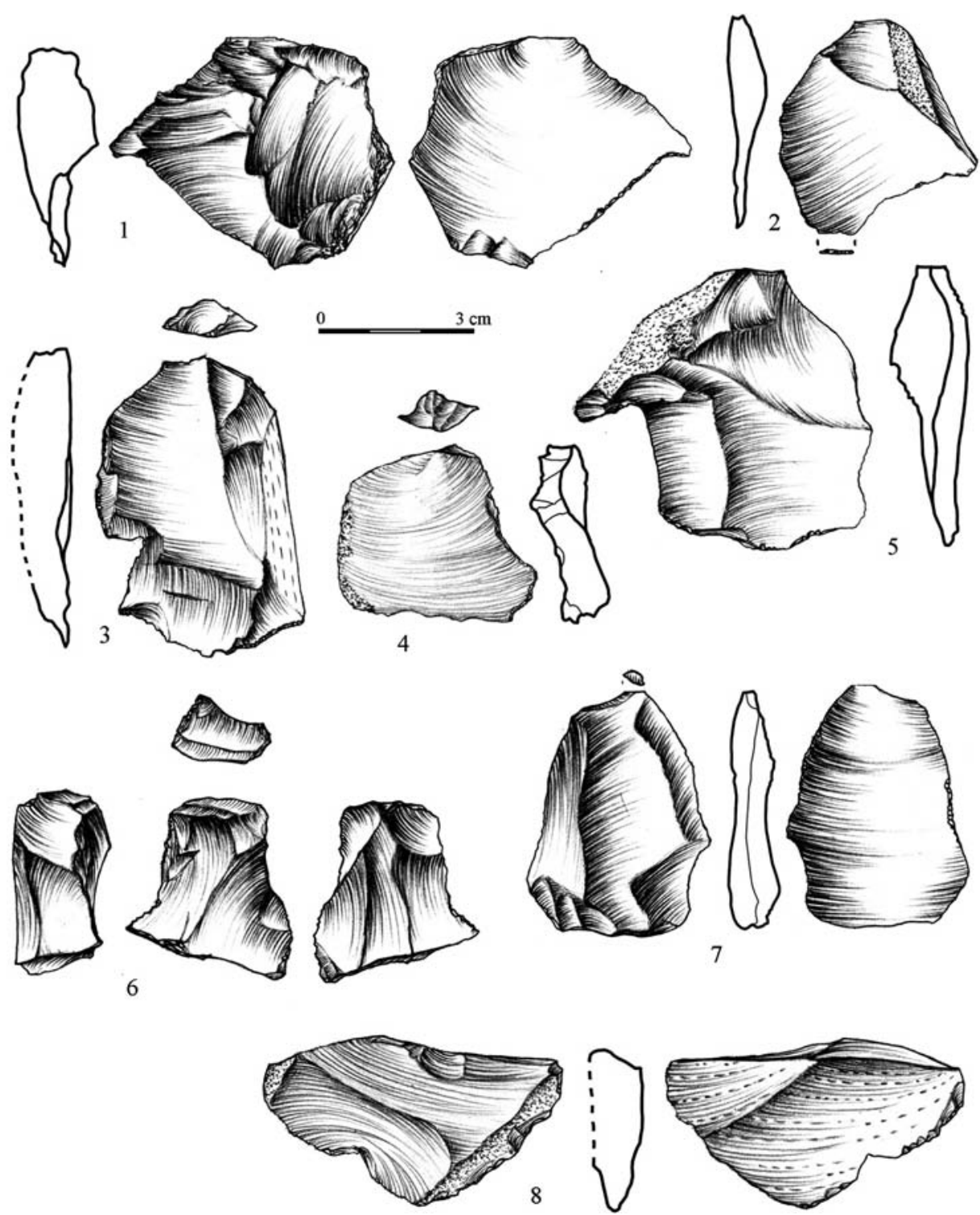

Fig. 15. Wilczyce, site 10, feature 13. Flint inventory. 1-8-tools.

In total, nine artefacts have use-wear transformations.

The massive scraper was very intensively used for scraping hide (figs. 22: 1; 23: 1a) and on lower parts of its lateral edges, there are also visible traces which may be associated with a potential haft (fig. 23: 1b).

Transformations recorded on lateral edges of the truncated blade (fig. 22: 2) most probably were caused by using the tool to work in bone/antler (fig. 23: 2).

No use-wear transformations were identified on edges of the scraper, however, such marks were visible on the grover sting of the perforator (fig. 22:4) - they were the result of carving in an unidentified material. 

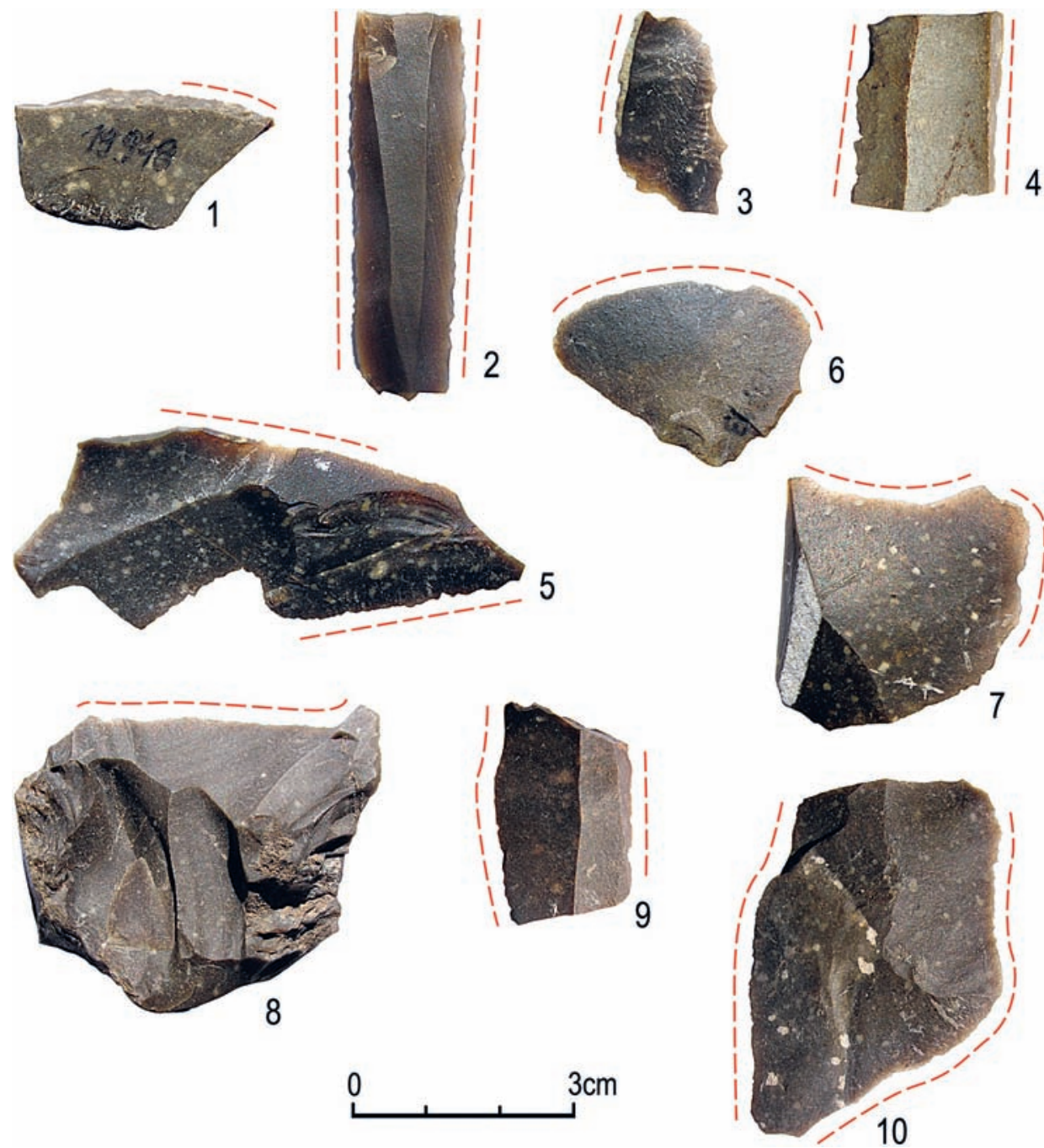

Fig. 16. Wilczyce, site 10, feature 13. Flint artefacts with evidence of use-wear: --- presence of use-wear traces; 1 -scraper; 2 - truncated blade; 3, 4 -retouched blades; 5-8-retouched flakes; 9 - unworked blade; 10 - unworked flake.

The denticulate tool (fig. 22: 5) was used for processing plants, whereas the retouched blade (fig. 22: 6 ) for boring holes in a hard material (wood or bone/antler), while probably the working part of the tool the apex - was broken during its use.

Two of the three analysed retouched flakes were used for scraping an unspecified material (fig. 22: 9) and scraping and cutting plants/wood (fig. 22: 8).

The projectile point that came from the discussed feature (fig. 22:3) was broken when used as a point as indicated by the scar visible on the fracture of the broken transverse edge. No evident traces of using any haft have been identified, which in turn may be associated with the projectile point being firmly mounted in the haft.

The part of the tool was used for scraping an unspecified material (fig. 22: 7). 

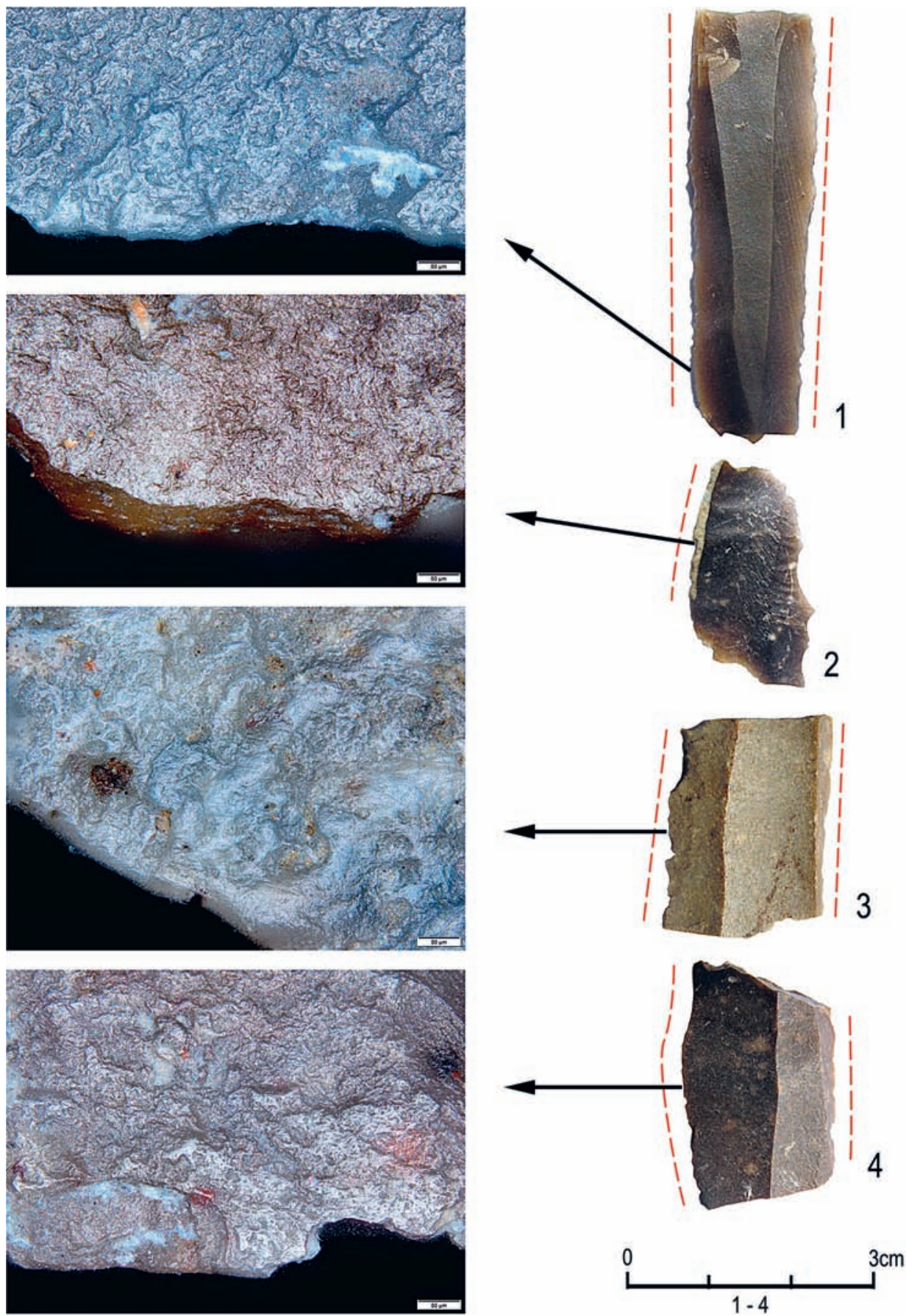

Fig. 17. Wilczyce, site 10, feature 13. Macroscopic photographs:1 - truncated blade, processing bone/antler; 2 - retouched blade, scraping bone 3 - retouched blade, processing bone/antler; 4 - blade, processing plants. 


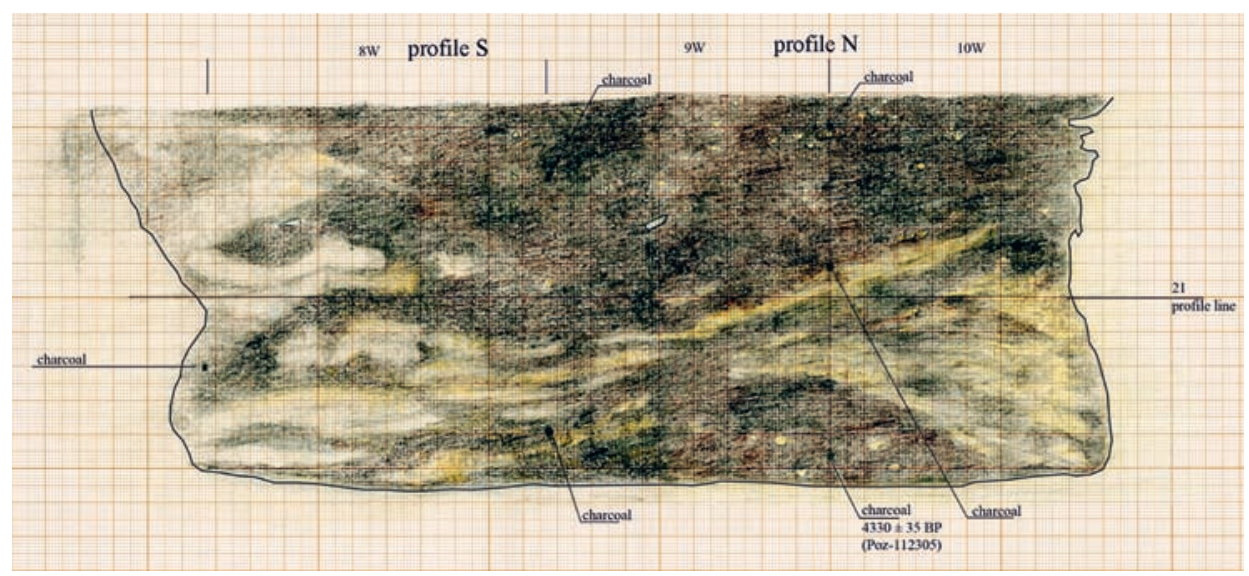

Fig. 18. Wilczyce, site 10. Profile of feature 19 (drawing E. Gumińska).

\section{Discussion}

\section{Evidence of axe manufacturing}

The production of axes is evidenced not only by the flakes but also by the presence of axes themselves in the inventory.

The axe excavated from feature 13 made from chocolate flint has a regular and symmetrical outline, with all surfaces carefully and precisely worked. In this case, there is a visible tendency to create optimal tetrahedral shapes. It can be certainly classified as a typical form (Libera 2004, 107; 2009, 169).

The second specimen is an axe made from banded flint. It was registered in feature 5 and is smaller than the axe from feature 13 , but it is a finished product with polished all surfaces.

Axes were also manufactured from Świeciechów flint, as indicated by the retrieved waste material in the form of flakes (figs. 12: 6 and 8-9; 13:1, 3;20:2). This is confirmed by their diagnostic features such as: a platform angle of 90 degree, a pronounced bulb, a flat profile, and a lenticular platform shape (Högberg et al. 2001, 207).

\section{Flakes}

It is the largest group of finds. The largest flake forms were recorded in feature 13, while the smallest range of variations in size and thickness showed flakes from feature 5 (fig. 24a-b).

Production of flakes is associated with the manufacture of tetrahedral forms and exploitation of flake cores. Three cores were registered. The first one was made from chocolate flint (feature 13) and two others from banded flint (feature 5). They are probably residual forms of four-sided axes. Removal scars visible on surfaces of the cores are small, which corresponds well with the size with the flakes from these raw materials, whereas without doubts - not all Świeciechów flint flakes should be associated with the production of axes. The presence of specimens with one- and multi-directional scars probably 


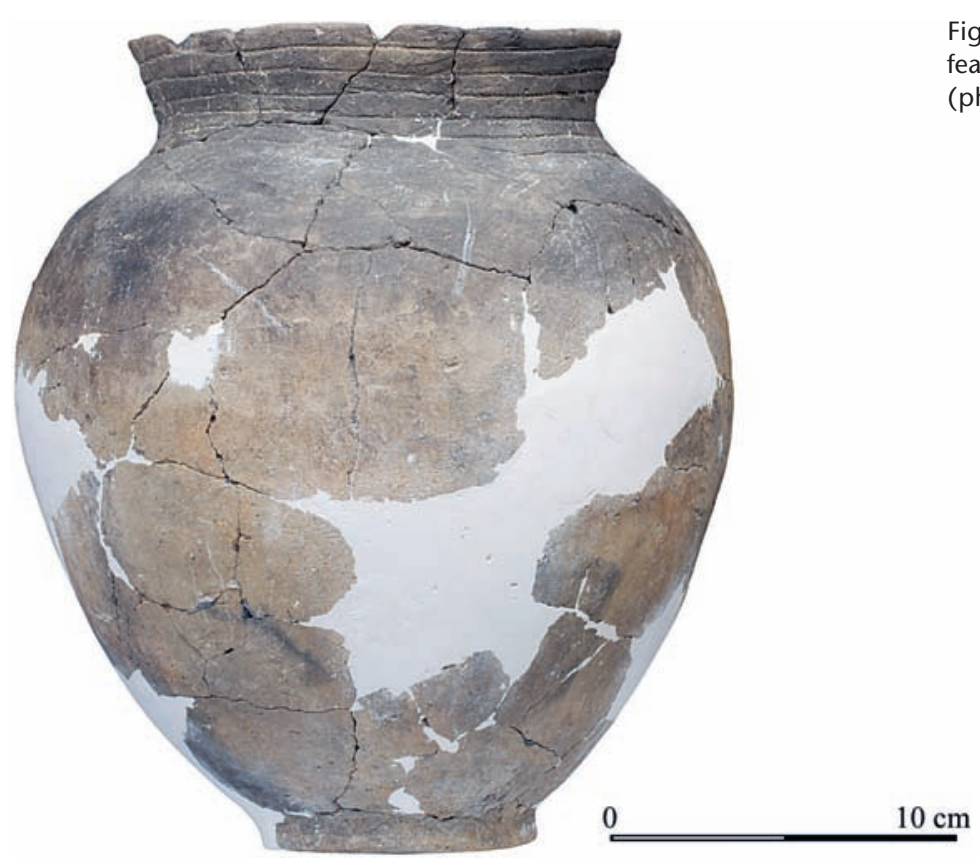

Fig. 19. Wilczyce, site 10, feature 19. Pottery vessel (photo M. Osiadacz).

is the evidence of the exploitation of single and multi-platform cores. These suggestions conform with the results of studies on flint production in the case of other assemblages of the Globular Amphorae culture (Vencl 2000; Kabacinski - Sobkowiak-Tabaka 2005, 57; Stanisławski - Wojnicka 2012, 166-167; Kopacz - Přichystal - Šebela 2014, 31).

Despite the fact that there were five identified splintered pieces, no flakes produced with that technique were recorded in the analysed material. This is a significant difference compared, for instance, with inventories from the area of Kuyavia, where sometimes $31 \%$ of specimens (Kabaciński 2008, 178) and in some cases, even more, were created by splintering (Czebreszuk - Szmyt 1992, 122, table 28). Similar proportions were also recorded at the Chociwel site located in Lower Silesia, where scaled flakes constituted $41 \%$ of the inventory (Bronowicki 1998, 175).

\section{Blades}

The longest specimens from Wilczyce are slightly over $60 \mathrm{~mm}$ long and in addition, are missing either bulbar or apex parts. The size of blades and their straight edges suggest that cores were rather large and flaking surfaces must have had regular shape.

Parameters of the blade semi-raw material, and the tools produced from it, indicate that they were removed from cores with narrow and broad flaking surfaces. An example of a core with a narrow flaking surface is the specimen discovered in Huta (Chełm district) site 2 (Bronicki 2016, 70-71), while from cores with broad flaking surfaces came a series of blades that constituted grave goods deposited in a burial pit at the site in Koszyce (Lesser Poland) (Przybyta et al. 2013, 28-30, table 23-31) and blades from the grave goods assemblage recorded at the Pevestorf site (Meyer 1988, 80). 


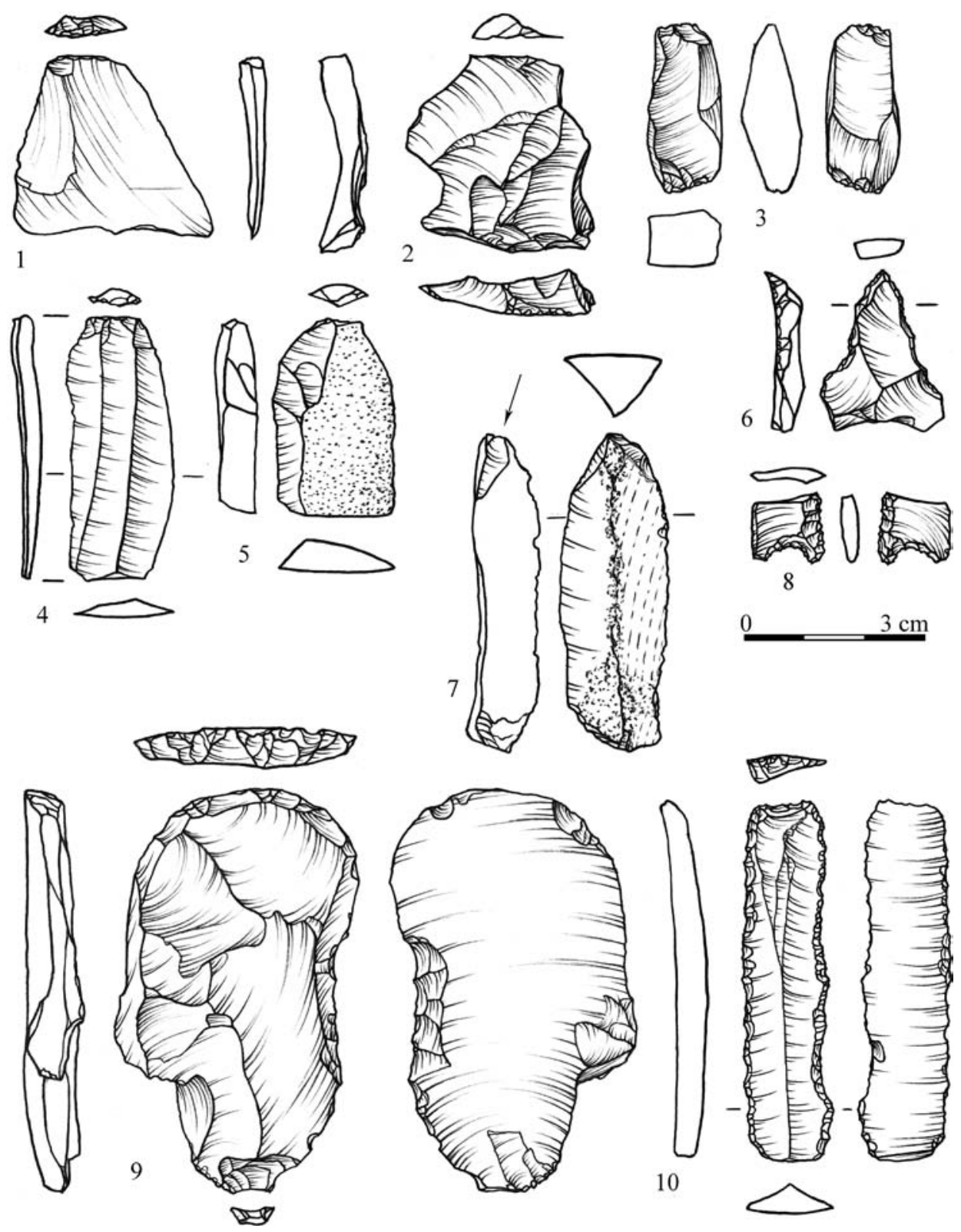

Fig. 20. Wilczyce, site 10, feature 19. Flint inventory. 1-2 - flakes; 3 - splintered piece; 4-5 - blades; 6-10 tools.

Based on model specimens of blades and tools created from them, two production methods were identified:

1) Using the pressure technique. Blades obtained with that technique have straight edges, uniform thickness throughout their entire length and smooth scar surfaces without 

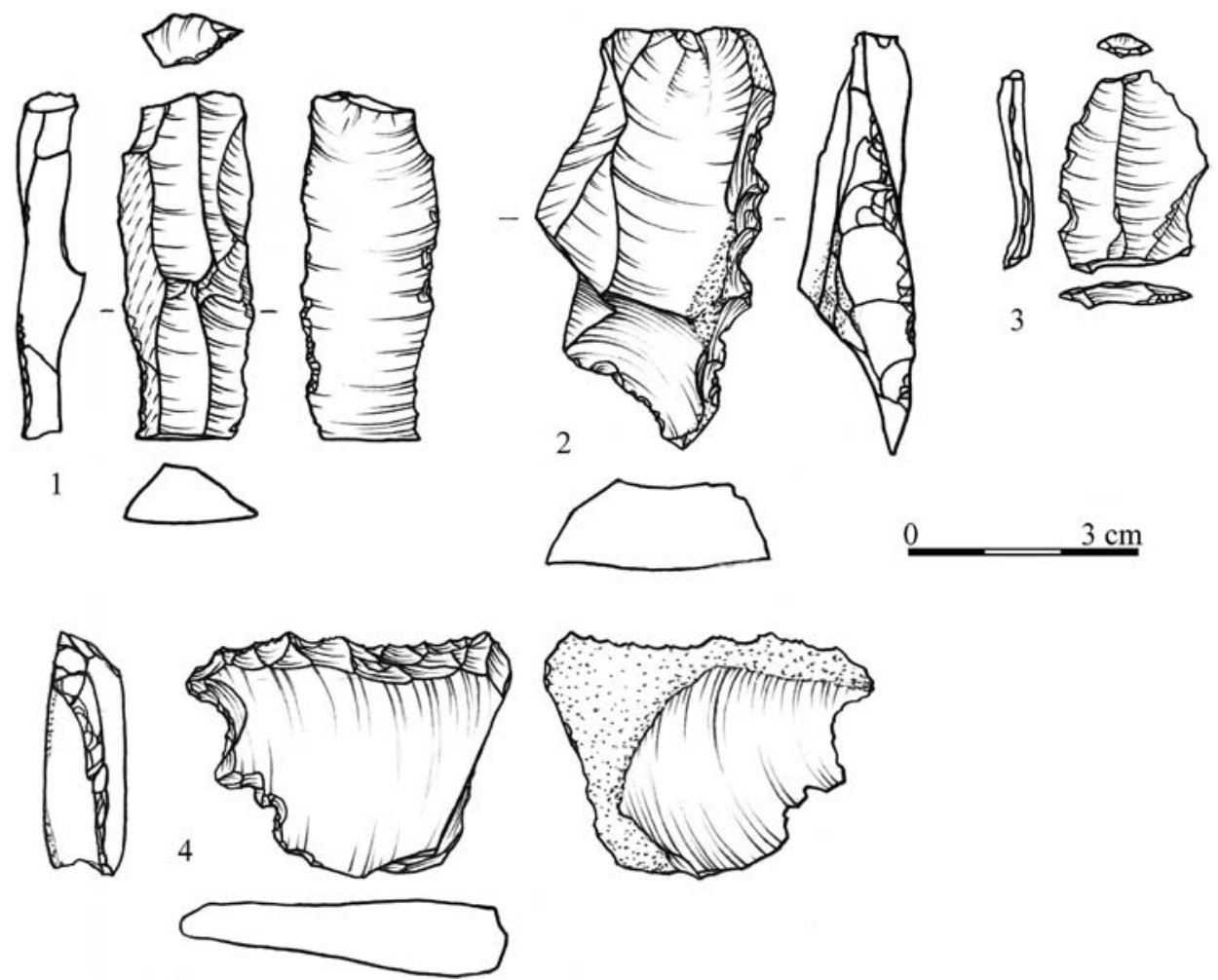

Fig. 21. Wilczyce, site 10, feature 19. Flint inventory. 1-4-tools.

visible ripples (figs. 7: 7; 13: 8). The use of that technique was recorded most probably in the case of the group of finds from the site in Koszyce (Proszowice district; BudziszewskiGrużdź 2013, 169) and other individual finds (Migal 2006, 526);

2) With a punch. These blades have similar morphological features as those mentioned above, but ripples are more visible (fig. 7: 4, 6).

\section{Tools}

Tools were produced from flake semi-raw material (endscrapers, notched blades, perforators, denticulate tools, scrapers, and borers) and blade semi-raw material (truncated blades and burins).

On the metric diagram, there are two identifiable sets of points - the first one represents primarily blade tools and a small portion of flake tools. That assemblage includes almost all artefacts discovered in features 5 and 19, while the second - almost exclusively artefacts from feature 13 (fig. 25a). Similar relationships between the parameters and the category of artefacts were recorded in the case of the thickness and width diagram (fig. 25b).

Observations made in the case of the flint inventory of the Globular Amphorae culture from Mierzanowice (Balcer 1963, 119) and the refitting from feature 11 of the Corded Ware culture from the site Wilczyce 10 (Boron 2018; 2020), indicate that flakes obtained 

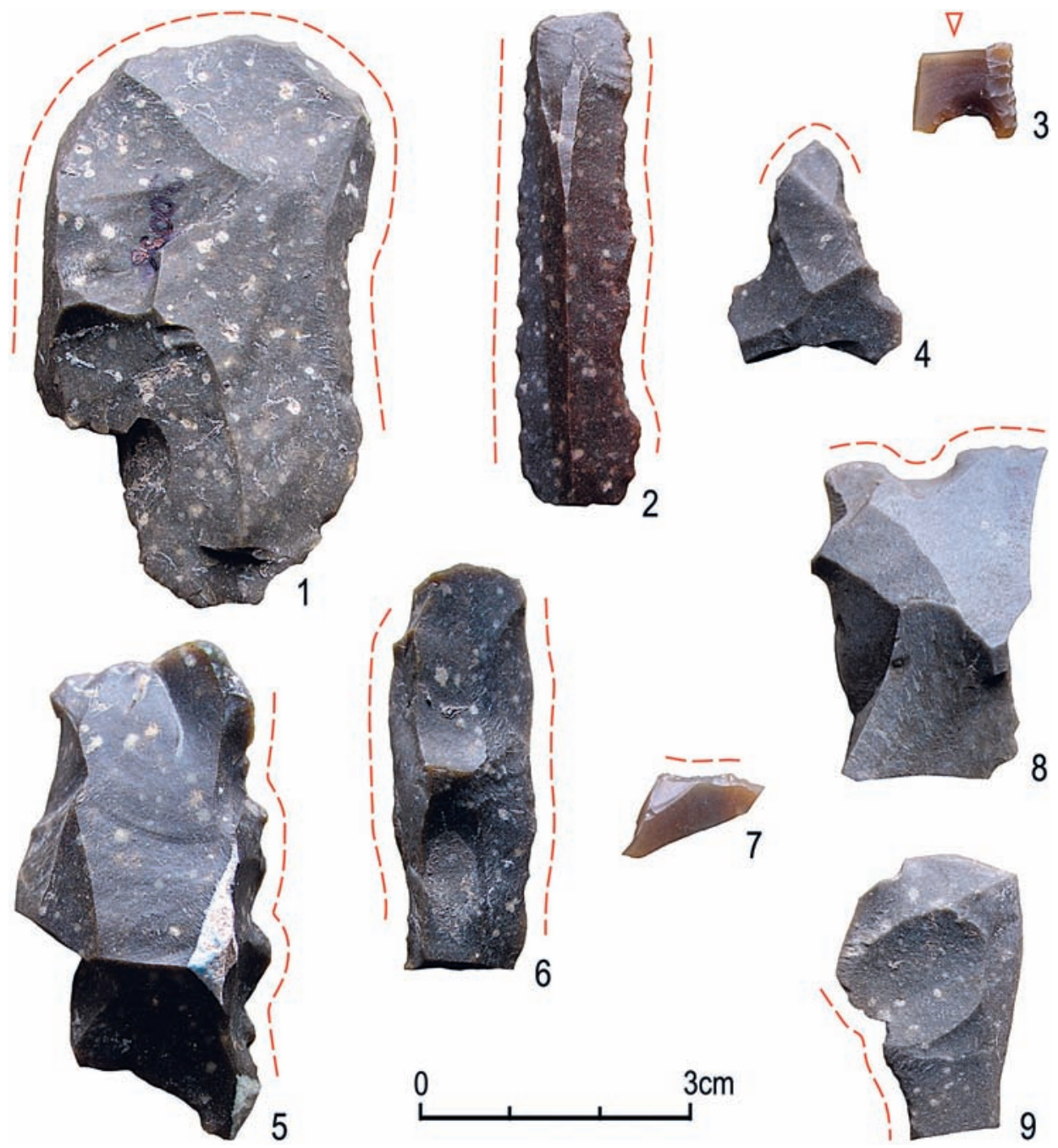

Fig. 22. Wilczyce, site 10, feature 19. Flint artefacts with evidence of use-wear: --- presence of use-wear traces; 1 - endscraper; 2 - truncated blade; 3 - projectile point; 4 - perforator; 5 - denticulate tool; 6 - retouched blade; 7 - fragment of a tool; $8-9$ - retouched flakes.

during the manufacturing of four-sided axes were also used to make tools, which - without doubts - is also true in the case of inventories from the analysed features. These are primarily retouched flakes and other small tools that can be referred to as "informal tools" (Andrews - Greubel 2008, 29-30).

In the case of the tools, in addition to the already mentioned truncated blades, which are the most characteristic blade tools of the Globular Amphorae culture (Balcer 1983, 216), our attention is also drawn to the presence of two burins. In the case of the former, a morphologically similar specimen of a truncated blade was discovered at the Puławy-Włostowice site (Niezabitowska-Wiśniewska - Wiśniewski 2018, 280), while burins are only 

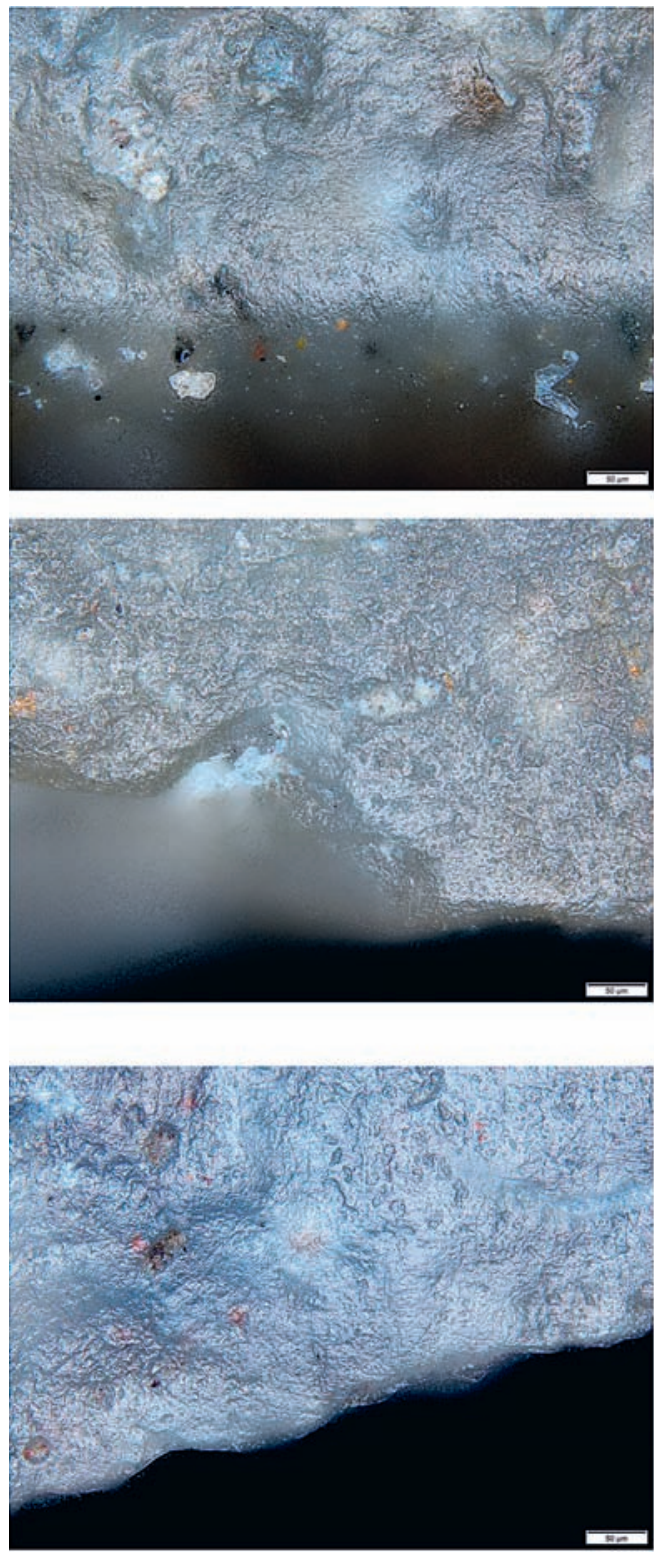
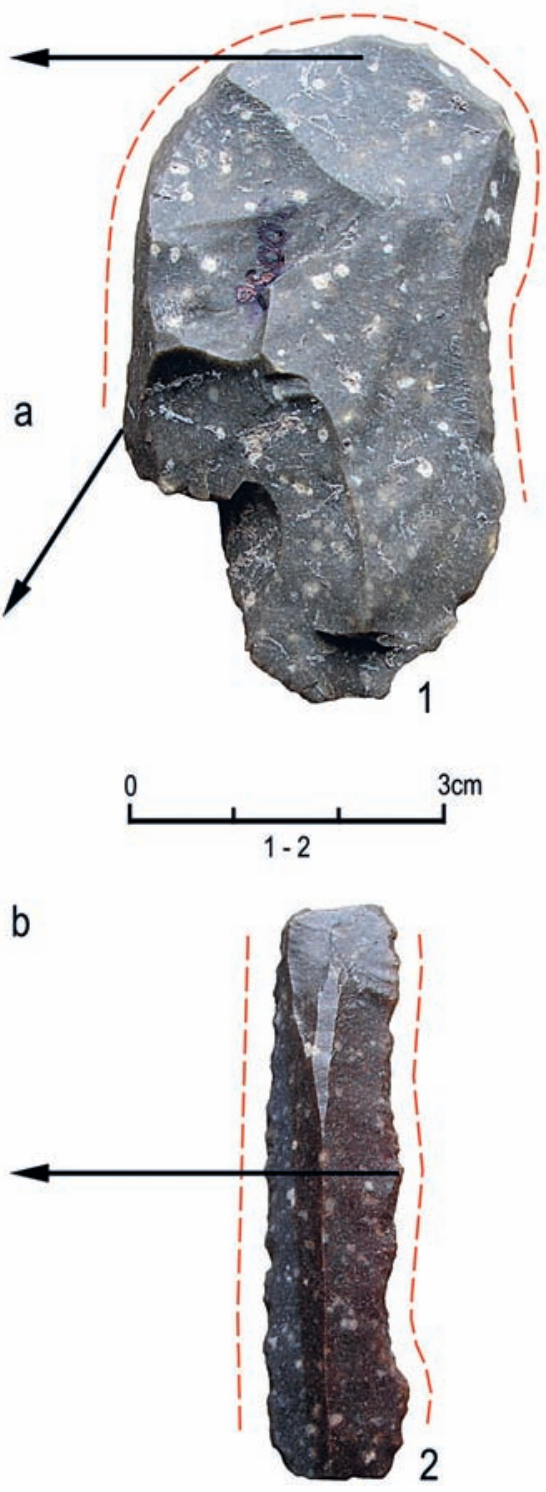

Fig. 23. Wilczyce, site 10, feature 19. Microscopic photographs: 1-endscraper, a - scraping hide; b-marks left by the haft; 2 - truncated blade, traces associated with the processing of bone/antler.

sporadically recorded finds. Among the grave goods from the Lublin Upland only one specimen of such tool has been identified to date (Bronicki 2000; 2016, 56-57). The same applies to Podlasie and Mazovia, where only one specimen was discovered in a grave in the village of Zaborze (Nasielsk commune; Mazurowski 1977, 162; Gawrońska - Białowarczuk 2011). 


\section{Discussion concerning the results of the microscopic analysis}

The traseological study of the finds demonstrated that in each feature there were artefacts with evidence of use-wear ( $t a b .2)$. In the case of the core and splintered pieces, there were deformations associated with their preparation and subsequent exploitation to produce semi-raw material. Artefacts from features 5, 13, and 19 were made not only from the collected flint raw material but also damaged or flawed axes, the remains of which - manifesting as polished surfaces - were observed on the surface of the splintered piece and the unworked flake.

Economic activities associated with the analysed features required using both typological tools and semi-raw material in the form of unworked blades and flakes. The intensity with which these artefacts were used differed, although in most cases they were heavily exploited. An example of long-term use is the chunky endscraper - its front and lateral edges became rounded as a result of its use, which is visible with the naked eye (fig. 22: 1). These traces, together with the burnishing that is visible at a higher magnification, are the argument to support the thesis that the tool was used for a long time for scraping dry hides. The endscraper was most probably wrapped with leather to protect hands during work, which is indicated by the traces observed on lower parts of the lateral sides of the tool.

In addition to scraping hides - an activity that was a very important part of the longer process associated with leather dressing, another activity documented by the presence of use-wear marks on several specimens was the processing of plants. Traces associated with treating plants were recorded on the edges and surfaces of truncated blades, retouched blades and flakes, the denticulate tool, and unworked blades and flakes. The processing of plants covers a wide range of activities. The recorded use-wear evidence - chips, grazes, light and shiny burnishing or - the opposite - matt areas with scratch marks caused by contact with abrasive material, covering large parts of surfaces of the artefacts or located only on their edge - not only indicates the variety of performed actions - cutting, scraping and splintering - but also the diversity of plants that were treated. Except for one specimen, all finds from the analysed features were used for several different activities. Apart from the truncated blade discovered in feature 5, which might have been used as a part of a composite tool for reaping crops (fig. 8: 2), the remaining artefacts were probably used for processing plants that were essential ingredients of the everyday diet and to manufacture everyday objects. These may have been fine branches, twigs, birch bark, nettle, linen fibres, or other plants. Residues of some of them, in the form of macroremains, were discovered in Late Neolithic features, thus confirming their use (Lityńska-Zajac 2005; 2008) by specific communities. The analysed assemblage also contained tools for scraping and cutting wood. Furthermore, traces associated with woodworking were discovered on the cutting edge of the flint axe.

In addition to treating hides and wood, several artefacts bear evidence of activities associated with scraping bone, processing bone/antler, and scraping some sort of an unspecified non-organic material, and the broken projectile point served as an arrowhead mounted on a shaft.

The assemblage of flint materials from feature 19 was the largest of all assemblages analysed in this paper (tab. 2) and compared to the other two features had the greatest number of specimens with identified use-wear traces, whereas - proportionally - the greatest number of used finds compared with the total number from the feature was recorded 


\begin{tabular}{|c|c|c|c|}
\hline & Feature 5 & Feature 13 & Feature 19 \\
\hline Analysed artefacts (total) & 17 & 31 & 21 \\
\hline unused & 7 & 17 & 12 \\
\hline used & 10 & 14 & 9 \\
\hline raw material and activities & & & \\
\hline hides & & & \\
\hline scraping & & & 1 \\
\hline wood & & & \\
\hline scraping & & 1 & \\
\hline processing & 1 & 1 & \\
\hline plants/wood & & & \\
\hline scraping & & 1 & 1 \\
\hline processing & 1 & 1 & \\
\hline plants & & & \\
\hline cutting & 1 & & \\
\hline processing & 3 & 4 & 1 \\
\hline bone & & & \\
\hline scraping & & 1 & \\
\hline bone/antler & & & \\
\hline processing & & & \\
\hline point & & & \\
\hline non-organic raw material & & & \\
\hline scraping & & & \\
\hline soft raw material & & & \\
\hline cutting & & & \\
\hline hard raw material & & & \\
\hline boring & & & \\
\hline unspecified & & & \\
\hline boring/carving & & & \\
\hline scraping & & & \\
\hline cutting & & & \\
\hline strike-a-light tools ? & & & \\
\hline
\end{tabular}

Tab. 2. Total numbers of analysed, unused and used artefacts, showing the raw materials and work performed in features.

in the case of feature 5. Activities performed by the community that created features 5 , 13, and 19 were associated with the settlement and occupation of the site, with working in wood and processing plants being the dominating type of actions. Feature 19 is characterised by the presence of the intensely used endscraper and a weaponry artefact (arrowhead), while feature 13 contains tools used for scraping bone and processing bone/antler. It is worth noting the presence in feature 5 of a flint axe, carefully polished and smoothed, used for settlement-type woodworking.

Flint materials of the Globular Amphorae culture originating from different sites in Poland were subjected to a series of traseological analyses. Although the nature of those sites varies, they have one thing in common - they are assemblages with small numbers of artefacts. Site Kowal 14 located in Kuyavia Lake District (Pojezierze Kujawskie) was identified as a burial and ritual site (Osipowicz - Pomianowska-Makowiecki 2014). Five flint artefacts subjected to microscopic observations were used to punch leather, reap crops, and perform other unidentified activities. The flint axe discovered in the feature of the Globular Amphorae did not have any use-wear evidence and the presence of traces associated with the repair of the cutting edge should be interpreted as an element of a funerary 

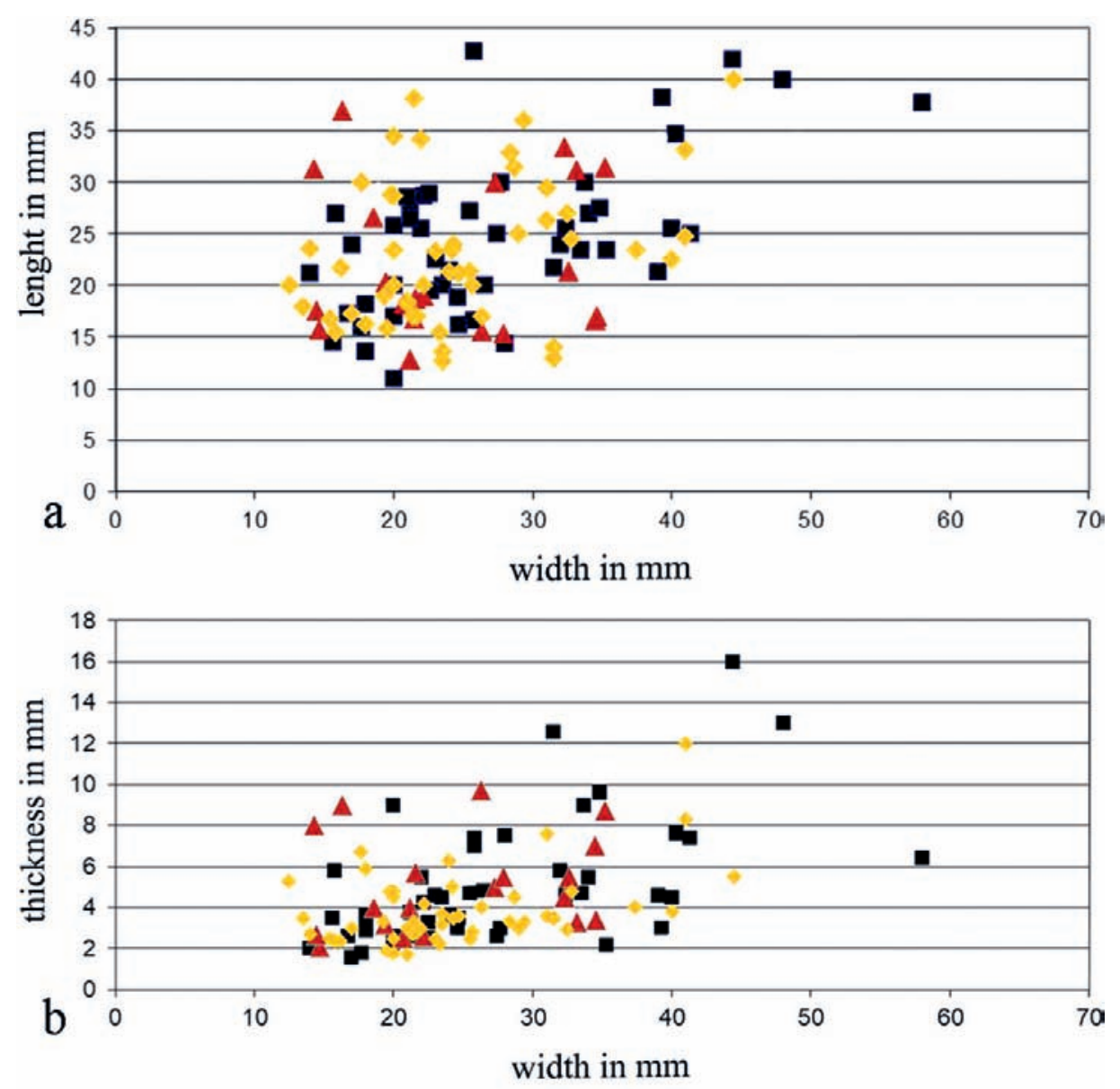

1 느 3

Fig. 24. Wilczyce, site 10. Metric diagrams of flakes. 1 - feature $13 ; 2$ - feature $19 ; 3$ - feature 5.

ritual. At the multi-culture site in Ludwinów (Kuyavia) archaeologists also discovered remains of the Globular Amphorae culture settlement, including two flint axes that most probably were used for working in wood (Winiarska-Kabacinska 2017a). They were parts of a grave goods assemblage. At the multi-culture site in Jordanów Śląski, six finds from a selected assemblage of artefacts linked to the Globular Amphorae had use-wear traces. They were the result of processing herbaceous plants, wood, and bones, while the projectile point was used as a point (Kufel-Diakowska-Mozgała-Swacha-Bronowicki 2018). The analyses of artefacts from a grave on site 3 in Koszyce (Lesser Poland) indicated that ten artefacts had use-wear traces and were used for processing plants (crops), scraping hide, and butchering (Pyżewicz 2013). Flint axes and chisels from that grave partly bore marks left by work associated with processing organic materials and partly were unused. The flint material discovered in the megalithic tomb in Kierzkowo in the Pałuki region showed the presence of three specimens with use-wear traces, which were used for scrap- 

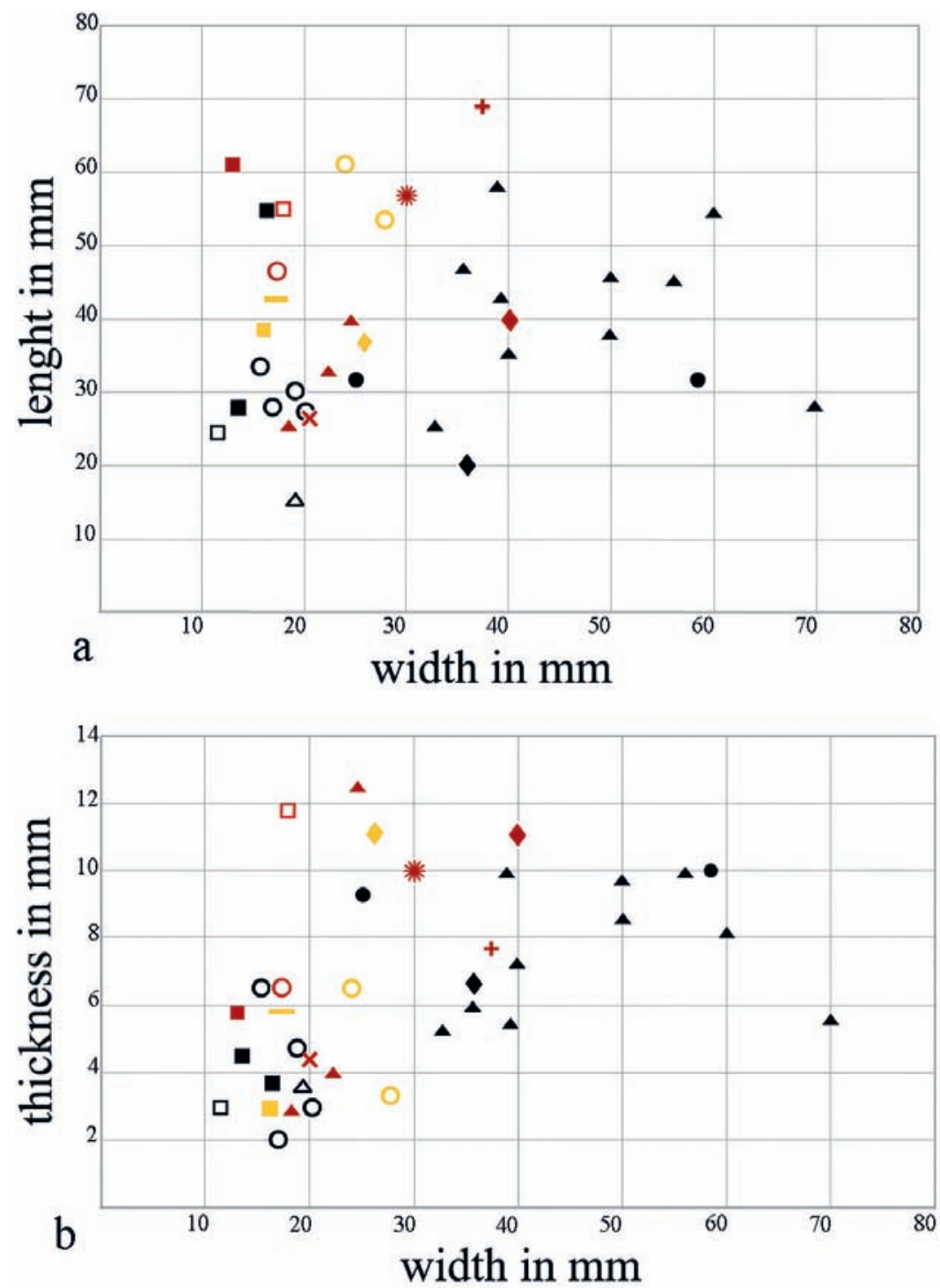

$1 \square 2 \square 3 \bullet 405$ 䊑 $6+7 \times 8-9 \diamond 10 \triangle 11$

Fig. 25. Wilczyce, site 10. Metric diagrams of tools. 1 - truncated blades; 2 - burins; 3 - retouched chunks; 4 - retouched blades; 5 - denticulate tools; 6 - endscrapers; 7 - perforators; 8 - borers; 9 - scrapers; 10 - notched blades; 11 - retouched flakes. Key: yellow colour - feature 5; black - feature 13; red - feature 19.

ing wood, reaping crops, and treating some sort of a hard raw material (Winiarska-Kabacińska 2017b).

The above-mentioned results of traseological studies indicate the diverse range of activities that were performed by the Globular Amphorae culture community, and the observa- 
tions made during the analyses of the artefacts from Wilczyce fall into line with the findings made at other Globular Amphorae culture sites, both sepulchral and settlement sites. The specific aspect of the site in Wilczyce is the much more visible treatment of plants, the processing of which may have been associated with the greater demand of the Late Neolithic communities for plant-based products (Van Gijn 2010).

\section{Final remarks}

The analysis of the structure of materials from features 5, 13, and 19 demonstrated that Świeciechów flint was the basic raw material treated by the Globular Amphorae culture communities, whereas banded flint was definitely less important for flint manufacturing activities. It is a very different situation to that known from the settlements in Mierzanowice (Balcer 1983, 118) and Krzczonowice (Jedynak 2009, 166). According to Budziszewski's (1990) findings for grave and settlement-type inventories from the territory of Mazovia, blades and tools made from blades were primarily produced from chocolate flint and Turonian flint (Świeciechów, Gościeradów, and Ożarów flint), whereas axes - from banded and Świeciechów flint. Similar relationships were recorded in the case of the site in Wilczyce, with the provision that in this case chocolate flint was also used for the manufacturing of axes.

Considering the nature of the obtained archaeological sources, it is a typical settlement-type material reflecting different activities and flint knapping concepts. That interpretation is based on the diverse set of tools and the small number of blades, which is very representative in the case of settlement sites. However, in this case, it is impossible to determine which of the performed activities was the leading one. Despite the settlement-type nature of the inventory, it stands out compared with others, not only those from the area of Lesser Poland but also other regions. Above all, there is the diversity of tool forms and the high quality of blade artefacts, especially truncated blades, produced from regular, slender blades.

Two separate and different assemblages of artefacts confirm the presence of two technological trends. The first one is associated with the manufacturing of tetrahedral forms, based on Świeciechów, chocolate, and banded flint, while the second one - with the blade and flake exploitation of cores that were produced from chocolate and Świeciechów flint. Without doubts, the execution of both trends was affected by the availability of good quality flint raw material, which is one of the key factors in organising the production (Andrefsky, Jr. 1994, 23).

However, the small number of flakes that came from the production of axes seems to prohibit us from formulating the thesis that the analysed material is the residue of specialised flint workshops associated with the manufacturing of four-sided forms, as this was in the case of the Corded Ware culture communities (Boron 2017; 2018). It was rather an individual production motivated by the current demand for that type of artefacts and it seems that they were a constant element of the equipment used in the discussed settlement.

Perhaps the axes were brought to the site following their preliminary treatment, and in the settlement, they were only undergoing the final stages of the manufacturing process. A similar interpretation associated with the production of axes was formulated on the basis of the analysis of the material from the settlement in Ślęza 11/12 (Bronowicki 2003, 60). 

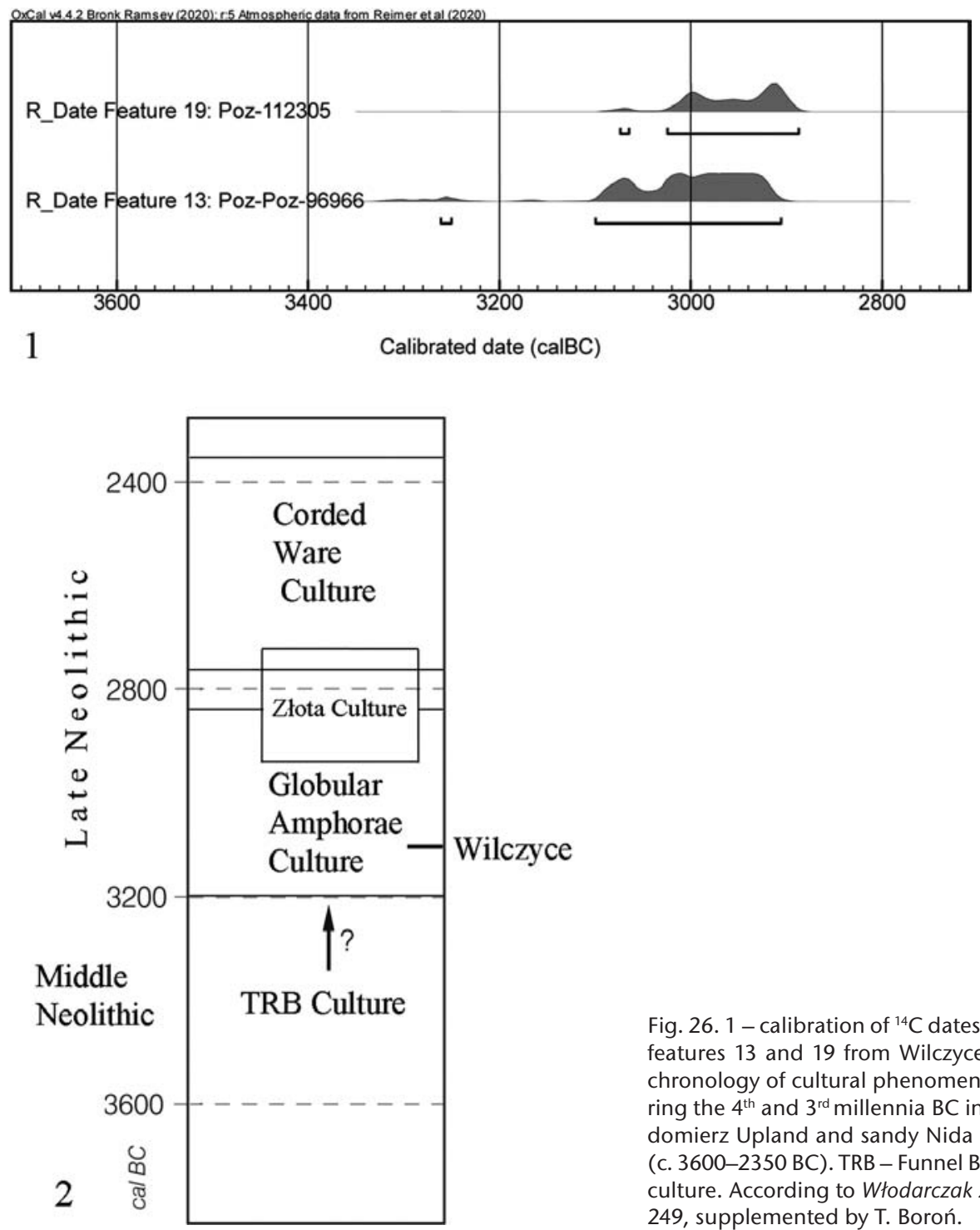

Fig. 26. 1 - calibration of ${ }^{14} \mathrm{C}$ dates from features 13 and 19 from Wilczyce; 2 chronology of cultural phenomena during the $4^{\text {th }}$ and $3^{\text {rd }}$ millennia BC in Sandomierz Upland and sandy Nida Basin (c. 3600-2350 BC). TRB - Funnel Beaker culture. According to Włodarczak 2008, 249, supplemented by T. Boroń.

As already signalled, the presented flint inventory stands out from other assemblages defined as settlement-type inventories because of its structure. In particular, the presence of blades and blade tools is in this case the factor that determines its high research potential. That type of artefacts is much more often recorded in grave goods assemblages (Nosek 1950, 72, 120; Wiślański 1966, 225; Halicki 1970, 307; Mazurowski 1977; Bąbel 1979, 71; Ścibior - Ścibior 1990, 189; Ścibior - Kokowski - Koman 1991, 88; Juchelka 2009, 96) than in waste material from settlements. However, fairly large assemblages of blades and blade tools were collected from features discovered in the settlements in Mierzanowice (Balcer 1963) and Opava-Kateřinky-Malé Hoštice (Kopacz - Přichystal - Šebela 2014, 
110-111). This provides us with the opportunity to make some comparisons in terms of technological and organisational aspects of flint production. In the case of both abovementioned assemblages, like in the case of Wilczyce, researchers recorded broad tool spectrums.

In Mierzanowice, based on the recorded archaeological material and its classification, we also can talk about two independent flint production trends: the manufacturing of axes and the exploitation of blade and flake cores. Size parameters of the blades were similar to those recorded for the finds from Wilczyce, whereas at the above-mentioned site in Czechia the structure of the inventory indicates the exploitation of multi-dimensional and single platform blade cores. The lithic chipped industry was rather microlithic and its technological features suggest the use of a hard percussion. The third variant of creating semi-raw material is the splintering technique. These standards set out for the flint industry of the Globular Amphorae culture at the Czech site visibly differ from the technological indices diagnosed for the material that comes from the analysed features on the site in Wilczyce.

When we compare the results of flint knapping activities from the site Wilczyce 10 with other archaeological sources from regions characterised by the presence of worse quality raw materials or entirely lacking such resources, the manufacturing activity of the Globular Amphorae culture communities in those areas comes across as rather poor or limited.

At the site Domasław 35 (Kobierzyce commune) only 43 flints were collected from 30 excavated features, including 13 chunks (Sysiak - Waszczuk - Was 2010, 292), whereas at the site in Siciny (Góra district) located in Lower Silesia only two flints were recorded (Wojciechowski 1971, 63). Sparse flint materials were also discovered during archaeological works at the site Wilkostowo 23/24 Aleksandrów Kujawski commune; Domańska 2015, 320) and Janowice (Wrocław district; Sobkowiak-Tabaka 2016, 316). At another site in the Kuyavia region, archaeologists also recorded only several flint specimens, including unworked and retouched blades and a scraper (Grygiel 2013, 168). Redecz Krukowy site (Brześć Kujawski commune) was the place of production of mainly small flakes and splintered pieces (Papiernik - Płaza 2015, 229). A small number of flint artefacts was also unearthed in a Globular Amphorae culture feature at a site Lovosice in Czechia (Zápotocký - Dobeš 2000), where flint knapping activities were limited to producing flakes and flake tools (Vencl 2000).

The finds from Wilczyce analysed in this paper without doubts create an assemblage that is representative of the flint production of the Globular Amphorae culture in the area of Lesser Poland. This is highlighted not only by the similar raw material structure of the inventories but also the presence of diagnostic forms such as axes and regular blades. The selected archaeological sources thus constitute a diagnostic material that enabled us to carry out a detailed and comprehensive interpretation of flint manufacturing of the Globular Amphorae culture, and in terms of their typological and technological diversity it is unique for the eastern parts of Central Europe. In light of ${ }^{14} \mathrm{C}$ dates obtained from the analysis of samples of the charcoals retrieved from features 13 and 19 (fig. 26: 1) we may state that the Globular Amphorae culture communities that occupied the Wilczyce microregion were associated with the oldest settlement phase on the Sandomierz Upland (fig. 26: 2). This is also confirmed by ${ }^{14} \mathrm{C}$ dates with similar parameters obtained from other archaeological sites located in that area (Pasterkiewicz 2020, 70-71). 


\section{References}

Andrefsky, Jr., W. 1994: Raw-Material Availability and The Organization of Technology. American Antiquity $59,21-34$.

Andrews, B. W. - Greubel, R. A. 2008: Flaked Stone Tool Patterning as a Means for Inferring Fremont Obsidian Procurement and Exchange. Journal of California and Great Basin Anthropology 28, 23-41.

Balcer, B. 1963: Osada kultury amfor kulistych na stanowisku 1 w Mierzanowicach, powiat Opatów. Materiały Starożytne IX, 99-142.

Balcer, B. 1971: Kopalnia krzemienia w Świeciechowie-Lasku, pow. Kraśnik w świetle badań 1967 r. Wiadomości Archeologiczne 36, 71-132.

Balcer, B. 1975: Krzemień świeciechowski w kulturze pucharów lejkowatych. Eksploatacja, obróbka i rozprzestrzenienie. Wrocław: Zakład Narodowy im. Ossolińskich.

Balcer, B. 1983: Wytwórczość narzędzi krzemiennych w neolicie ziem Polski. Wrocław etc.: Zakład Narodowy im. Ossolińskich.

Bąbel, J. 1979: Groby neolityczne ze stan. I w Mierzanowicach, woj. tarnobrzeskie. Wiadomości Archeologiczne XLIV, 67-87.

Boró, T. 2013: Bogate wielofazowe osadnictwo z epoki kamienia. In: D. Główka et al. eds., Instytut Archeologii i Etnologii Polskiej Akademii Nauk 1953-2013, Warszawa: Instytut Archeologii i Etnologii PAN, 131-135.

Boroń, T. 2017: Manufacturing rectangular-sectioned axes in a Corded Ware culture in the light of refittings at Wilczyce 10, district Sandomierz (Poland). Archeologické rozhledy 69, 385-398.

Boron, T. 2018: Materiał odpadowy z produkcji siekier czworościennych z obiektów 1 i 11 ze stanowiska Wilczyce 10, pow. sandomierski. Materiały i Sprawozdania Rzeszowskiego Ośrodka Archeologicznego $39,57-69$.

Boroń, T. 2020: Flintknapping Technology of The Corded Ware Culture: Evidence from Wilczyce, Site 10 (Sandomierz District, Poland). Lithic Technology 45, 165-183. doi.org/10.1080/01977261.2020.1757213

Bronicki, A. 2000: Grób kultury amfor kulistych w Kolonii Czułczyce, stan. 6, gm. Sawin, pow. Chełm, woj. Lublin. Archeologia Polski Środkowowschodniej 5, 181-192.

Bronicki, A. 2016: Obrządek pogrzebowy społeczności kultury amfor kulistych na Wyżynie lubelskiej. In: P. Jarosz et al. eds., Schyłek neolitu na Wyżynie Lubelskiej, Kraków: Instytut Archeologii i Etnologii PAN, 45-256.

Bronowicki, J. 1998: Materiały krzemienne z osad kultury pucharów lejkowatych i kultury amfor kulistych z Chociwela, stan. I (aneks do artykułu P. Cholewy). Studia Archeologiczne XXX, 169-178.

Bronowicki, J. 2003: Osada ludności kultury amfor kulistych oraz inne przejawy osadnictwa neolitycznego na stanowisku Ślęza 11/12, pow. Wrocław. In: B. Gediga ed., Badania na autostradzie A4, część I, zeszyt 2. Archeologiczne Zeszyty Autostradowe, Wrocław: Instytut Archeologii i Etnologii PAN, 37-65.

Budziszewski, J. 1990: Uwagi o możliwościach porównania kujawskich i małopolskich inwentarzy krzemiennych kultury amfor kulistych. In: A. Cofta-Broniewska ed., Kultura amfor kulistych w rejonie Kujaw. Studia i materiały do dziejów Kujaw 4, Poznań: Wydawnictwo Naukowe UAM, 205-224.

Budziszewski, J. - Grużd́, W. 2013: O technikach i metodach krzemieniarskich. In: M. M. Przybyła et al. eds., Koszyce, stanowisko 3. Przemoc i rytuał u schyłku neolitu, Kraków - Pękowice: Stowarzyszenie Archaeologów Terenowych "Stater", Wydawnictwo i Pracownia Archeologiczna Profil-Archeo, 161-178.

Czebreszuk, J. - Szmyt, M. 1992: Osadnictwo neolityczne i wczesnobrązowe w Dębach woj. Włocławskie, stanowisko 29. Poznań - Inowrocław: Wydawnictwo Naukowe UAM.

Domańska, L. 2015: Flint materials. In: S. Rzepecki ed., Wilkostowo 23/24, A Neolithic Settlement in Kuyavia, Poland c. 3500 BC. Studien zur Archäologie in Ostmitteleuropa 15, Kraków - Bonn: Institute of Archaeology and Ethnology, Polish Academy of Sciences - Dr. Rudolf Habelt GmbH, 287-322.

Gawrońska, J. - Białowarczuk, M. 2011: Kultura amfor kulistych na nizinie północnomazowieckiej. Studia i materiały do badań nad neolitem i wczesną epoką brązu na Mazowszu i Podlasiu 1, 13-49.

Grygiel, R. 2013: Settlement of the Globular Amphora Culture at Site 6 in Lekarzewice near Osłonki in Kuyavia (Poland). In: S. Kadrow - P. Włodarczak eds., Environment and subsistence - forty years after Janusz Kruk's "Settlement studies". Studien zur Archäologie in Ostmitteleuropa 11, Kraków Bonn: Institute of Archaeology and Ethnology, Polish Academy of Sciences - Dr Rudolf Habelt GmbH, 163-172.

Halicki, M. 1970: Cmentarzysko kultury amfor kulistych i kultury pucharów lejkowatych w Klementowicach, pow. Puławy na stanowisku IV. Wiadomości Archeologiczne 35, 303-326. 
Haslam, M. 2006: Potential misidentification of in situ archaeological tool-residues: Starch and conidia. Journal of Archaeological Science 33, 114-121.

Högberg, A. -Apel, J. - Knutsson, K. - Olausson, D. - Rudebeck, E. 2001: The spread of flint axes and daggers in Neolithic Scandinavia. Památky archeologické 92, 193-221.

Jedynak, A. 2009: Depozyt półwytworów rdzeniowych narzędzi krzemiennych z osady ludności kultury amfor kulistych w Krzczonowicach, stan. 63, pow. Ostrowiecki. In: H. Taras - A. Zakościelna eds., Hereditas Praeteriti. Additamenta archaeologica et historica dedicata Ioanni Gurba Octogesimo Anno Nascendi, Lublin: Wydawnictwo UMCS, 157-166.

Juchelka, J. 2009: Nové nálezy eneolitických hrobových celků z Českého Slezska. Acta Musei Moraviae XCIV, 89-97.

Kabaciński, J. 2008: Inwentarze krzemienne ze stanowisk neolitycznych Kotliny Toruńsko-Bydgoskiej. In: J. Bednarczyk et al. eds., Na pograniczu światów. Studia z pradziejów międzymorza bałtycko-pontyjskiego ofiarowane profesorowi Aleksandrowi Kośko w 60 rocznicę urodzin, Poznań: Wydawnictwo Naukowe UAM, 168-190.

Kabaciński, J. - Sobkowiak-Tabaka, I. 2005: Osadnictwo kultury pucharów lejkowatych i kultury amfor kulistych w Mirkowicach, stanowisko 33, gm. Mieścisko, pow. Wągrowiec, woj. wielkopolskie. Fontes Archaeologici Posnanienses 41, 37-90.

Keeley, L. 1980: Experimental determination of stone tool uses: A microwear analysis. Chicago: University of Chicago Press.

Keeley, L. - Newcomer, M. 1977: Micro-wear analysis of experimental flint tools: A test case. Journal of Archaeological Science 4, 29-62.

Kopacz, J. - Přichystal, A. - Šebela, L. 2014: Lithic chipped industry of the Young Eneolithic in Moravia and Czech Silesia. Brno: Archeologický ústav AV ČR.

Kowalewska-Marszałek, H. 2019: The Funnel Beaker and Globular Amphora Cultures in the Sandomierz Upland in the Light of Settlement Research. Archaeologia Polona 57, 115-130. DOI:23858/APa57.2019.008

Kowalewska-Marszałek, H. 2002: Krzemień świeciechowski w neolicie Wyżyny Sandomierskiej. Kilka uwag na temat rozprzestrzenienia inwentarzy. In: B. Matraszek - S. Sałaciński eds., Krzemień świeciechowski w pradziejach. Materiały z konferencji w Ryni, 22-24.05.2000. Studia nad gospodarką surowcami krzemiennymi w pradziejach 4, Warszawa: Stowarzyszenie Naukowe Archeologów Polskich - Instytut Archeologii i Etnologii PAN, 177-207.

Kowalewska-Marszałek, H. - Wtodarczak, P. 2002: Wyniki badań powierzchniowych na stanowisku paleolitycznym w Wilczycach, pow. Sandomierz. Sprawozdania Archeologiczne 54, 21-60.

Kufel-Diakowska, B. - Mozgata-Swacha, M. - Bronowicki, J. 2018: Zabytki krzemienne z prac wykopaliskowych prowadzonych na przełomie XIX i XX stulecia na stanowisku 5 w Jordanowie Śląskim. Śląskie Sprawozdania Archeologiczne 60/2, 25-73.

Langejans, G. H. J. 2010: Remains of the day-preservation of organic micro-residues on stone tools. Journal of Archaeological Science 37, 971-985.

Libera, J. 2004: W dążeniu ku nowej syntezie. Wybrane zagadnienia krzemieniarstwa schyłkowego z dorzecza górnej i środkowej Wisły. Archeologia Polski 49, 106-124.

Libera, J. 2009: Czy siekiery krzemienne mogą być wyznacznikiem kultury amfor kulistych?. In: H. Taras A. Zakościelna eds., Hereditas Praeteriti. Additamenta archaeologica et historica dedicata loanni Gurba Octogesimo Anno Nascendi, Lublin: Wydawnictwo UMCS, 169-179.

Libera, J. - Zakościelna, A. 2002: Złoża krzemieni turońskich w przełomowym odcinku Wisy. In: B. Matraszek - S. Sałaciński eds., Krzemień świeciechowski w pradziejach. Materiały z konferencji w Ryni, 22-24.05.2000. Studia nad gospodarką surowcami krzemiennymi w pradziejach 4, Warszawa: Stowarzyszenie Naukowe Archeologów Polskich - Instytut Archeologii i Etnologii PAN, 93-109.

Lityńska-Zajqc, M. 2005: Rekonstrukcja procesów gospodarczych na podstawach botanicznych. In: M. Lityńska-Zając - K. Wasylikowa eds., Przewodnik do badań archeobotanicznych (= Vademecum Geobotanicum), Poznań: Sorus, 470-522.

Lityńska-Zajqc, M. 2008: Usable wild plants in the archaeological record from Poland: selected examples. In: Z. Sulgostowska - J. A. Tomaszewski eds., Man-Millennia-Environment. Studies in honour of Romuald Schild, Warsaw: Institute of Archaeology and Ethnology Polish Academy of Sciences, 107-112.

Mazurowski, R. F. 1977: Cmentarzysko ludności kultury amfor kulistych w Zaborzu, woj. ciechanowskie. Wiadomości Archeologiczne 42/3-4, 155-173.

Meyer, M. 1988: Flintzusammenpassungen aus neolithischen Gräbern von Pevestorf, Ldkr. Lüchow-Dannenberg. Die Kunde N.F. 39, 75-85. 
Migal, W. 2006: About the variability of reduction sequences of the Globular Amphorae Culture. In: G. Körlin - G. Weisgerber eds., Stone Age - Mining Age. Papers of the VIII International Flint Symposium, Deutsches Bergbau-Museum Bochum 13.-17. September 1999, Bochum: Deutsches Bergbau-Museum, 523-529.

Moss, E. 1983: The functional analysis of flint implements: Pincevent and Pont D'Ambon, two case studies from the French final Palaeolithic. British Archaeological Reports 117. Oxford: Archaeopress.

Niezabitowska-Wiśniewska, B. - Wiśniewski, T. 2018: Osadnictwo ludności kultur amfor kulistych i ceramiki sznurowej. In: B. Niezabitowska-Wiśniewska ed., Puławy-Włostowice. Wielokulturowe stanowisko z zachodniej Lubelszczyzny, Lublin: Instytut Archeologii UMCS w Lublinie, 262-282.

Nosek, S. 1950: Kultura amfor kulistych na Lubelszczyźnie. Annales Universitatis Mariae Curie-Skłodowska. Sectio F, Nauki Filozoficzne i Humanistyczne 5, 55-158.

Osipowicz, G. - Pomianowska, H. - Makowiecki, D. 2014: Wytwory krzemienne, kamienne, z kości, poroża i zębów zwierzęcych. In: G. Osipowicz red., Kowal 14. Miejsce sepulkralno-obrzędowe ludności kultury amfor kulistych, Toruń: Wydawnictwo Naukowe Uniwersytetu Mikołaja Kopernika, 91-117.

Papiernik, P. - Płaza, D. K. 2015: Zagospodarowanie przestrzeni w środkowej i młodszej epoce kamienia na stanowisku Redecz Krukowy 20, gm. Brześć kujawski, woj. kujawsko-pomorskie, w świetle metody składanek. Acta Universitatis Nicolai Copernici - Archeologia 34, 217-236.

Pasterkiewicz, W. 2020: The first radiocarbon dates for the Globular Amphora culture cemetery in Sadowie in the Sandomierz Upland. Analecta Archaeologica Ressoviensia 15, 53-75. DOI: 10.15584/anarres

Plisson, H. 1985: Etude fonctionelle d'outillages lithiques préhistoriques par l'analyse des micro-usures : recherche méthodologique et archéologique. Ph.D. Thesis. Université de Paris I, Pantheon Sorbonne, Paris.

Przybyła, M. M. - Wtodarczak, P-Podsiadto, M. - Tunia, K. 2013: Obiekty kultury amfor kulistych. In: M. M. Przybyła et al. eds., Koszyce, stanowisko 3. Przemoc i rytuał u schyłku neolitu, Kraków - Pękowice: Stowarzyszenie Archaeologów Terenowych "Stater" - Wydawnictwo i Pracownia Archeologiczna ProfilArcheo, 11-64.

Pyżewicz, K. 2013: Analiza traseologiczna materiałów krzemiennych. In: M. M. Przybyła et al. eds., Koszyce, stanowisko 3. Przemoc i rytuał u schyłku neolitu, Kraków - Pękowice: Stowarzyszenie Archaeologów Terenowych "Stater" - Wydawnictwo i Pracownia Archeologiczna Profil-Archeo, 179-200.

Schild, R. ed. 2014: Wilczyce. A Late Palaeolithic winter hunting camp in southern Poland. Warszawa: Instytut Archeologii i Etnologii PAN.

Semenov, S. A. 1964: Prehistoric technology: An experimental study of the oldest tools and artefacts from traces of manufacture and wear. London: Cory, Adams and Mackay.

Sobkowiak-Tabaka, I. 2016: Materiały krzemienne. In: M. Szmyt ed., Osadnictwo społeczności neolitycznych na stanowisku 2 w Janowicach, woj. kujawsko-pomorskie, Poznań: Wydawnictwo Naukowe UAM, 309-321.

Stanisławski, K. - Wojnicka, D. 2012: Osadnictwo neolityczne na stanowisku Wojkowice 15, gm. Żórawina. In: B. Gediga red., Osadnictwo neolityczne na stanowisku Wojkowice 15, gm. Żurawina. Badania na autostradzie A4. Część X. Archeologiczne Zeszyty Autostradowe Instytutu Archeologii i Etnologii PAN 8, Wrocław: Instytut Archeologii i Etnologii PAN, 7-179.

Sysiak, P. - Waszczuk, K. - Was, W. 2010: Settlement of Globular Amphora Culture at Domasław site 35, dolnośląskie Voivodship. Sprawozdania Archeologiczne 62, 237-333.

Ścibior, J. - Kokowski, A. - Koman, W. 1991: Zespoły grobowe kultury amfor kulistych z zachodniej części Wyżyny Wołyńskiej. Sprawozdania Archeologiczne 43, 79-108.

Ścibior, J. - Ścibior, J. M. 1990: Sandomierz 78 - wielokulturowe stanowisko z przełomu neolitu i epoki brązu. Badania ratownicze 1984 roku. Sprawozdania Archeologiczne 42, 157-201.

Van Gijn, A. L. 1989: The Wear and Tear of Flint. Principles of Functional Analysis Applied to Dutch Neolithic Assemblages. Analecta Praehistorica Leidensia 22. Leiden: Sidestone Press.

Van Gijn, A. L. 2010: Flint in focus. Lithic biographies in the Neolithic and Bronze Age. Leiden: Sidestone Press.

Vencl, S. 2000: Štípaná industrie z obiektu kultury kulovitých amfor z Lovosic. Památky archeologické 91, 151-152.

Winiarska-Kabacińska, M. 2017a: Wyniki obserwacji mikroskopowych wybranych materiałów krzemiennych ze stanowiska 3 w Ludwinowie, pow. Włocławek, woj. kujawsko-pomorskie. In: I. Marchelak et al. eds., Ratownicze badania archeologiczne na stanowisku 3 w Ludwinowie, pow. Włocławek, woj. kujawsko-pomorskie (trasa autostrady A-1). Via Archaeologica Lodziensis, t. VII, Łódź: Fundacja 
Badań Archeologicznych Imienia Profesora Konrada Jażdżewskiego - Muzeum Archeologiczne i Etnograficzne w Łodzi, 561-574.

Winiarska-Kabacińska, M. 2017b: Analiza funkcjonalna zabytków krzemiennych pochodzących z megalitycznego grobowca z Kierzkowa na Pałukach. In: I. Sobkowiak-Tabaka et al. eds., Megalityczny grobowiec kultury amfor kulistych z Kierzkowa. Milczący świadek kultu przodków z epoki kamienia, Biskupin: Muzeum archeologiczne w Biskupinie, 151-159.

Wiślański, T. 1966: Kultura amfor kulistych w Polsce północno-zachodniej. Wrocław - Warszawa - Kraków: Zakład Narodowy im. Ossolińskich.

Wtodarczak, P. 2008: Corded Ware and Baden Cultures Outline of Chronological and Genetic Relations based on the Finds from Western Little Poland. In: M. Furholt et al. eds., The Baden Complex and the Outside World. Proceedings of the 12th Annual Meeting of the EAA in Cracow 19-24th September 2006. Studien zur Archäologie in Ostmitteleuropa 4, Studia nad Pradziejami Europy Środkowej 4, Bonn: Dr. Rudolf Habelt $\mathrm{GmbH}, 247-261$.

Włodarczak, P. - Boroń, T. - Kurzawska, A. - Osypińska, M. - Szczepanek, A. - Winiarska-Kabacińska, M. 2016: Grób kultury ceramiki sznurowej ze stanowiska $10 \mathrm{w}$ Wilczycach, pow. sandomierski. Przegląd Archeologiczny 64, 29-57. DOI 10.23858/PA64.2016.002

Wojciechowski, W. 1971: Osada ludności kultury amfor kulistych w Sicinach, pow. Góra. Sprawozdania Archeologiczne 22, 37-65.

Zápotocký, M. - Dobeš, M. 2000: Sídliště kultury kulovitých amfor z Lovosic k typologii keramiky KKA v Severozápadních Čechách. Památky archeologické 91, 119-150.

TOMASZ BOROŃ, Interdisciplinary Center of Archaeological Research, Polish Academy of Sciences, Al. Solidarności 105, PI-00-140 Warszawa; archeo.boron@gmail.com; ORCID: 0000-0001-9831-3950 MAtGORZATA WINIARSKA-KABACIŃSKA, Poznań Archaeological Museum, Wodna 27, PI-61-781 Poznań mwinkab@interia.pl; ORCID: 0000-0001-5927-8873 